September 2004 - NREL/TP-620-36833

\title{
Trends in Utility Green Pricing Programs (2003)
}

\section{Lori Bird and Karen Cardinal}

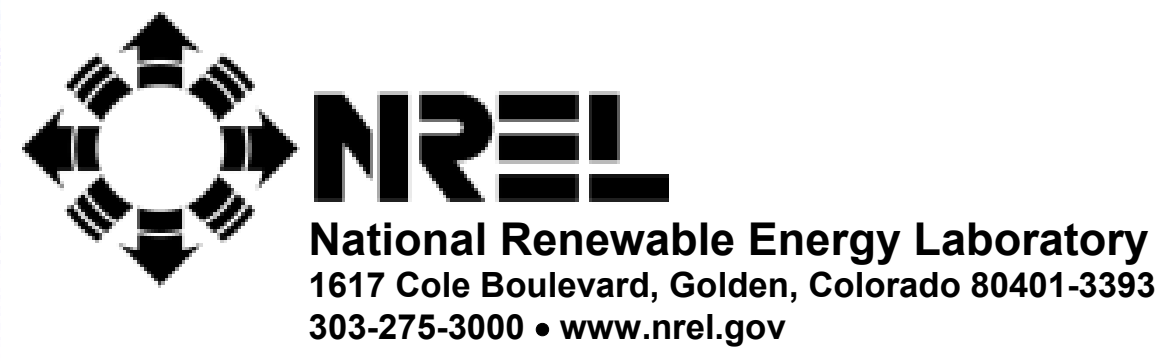

Operated for the U.S. Department of Energy Office of Energy Efficiency and Renewable Energy by Midwest Research Institute $\bullet$ Battelle 


\section{Trends in Utility Green Pricing Programs (2003)}

\section{Lori Bird and Karen Cardinal}

Prepared under Task No. ASG4.1003

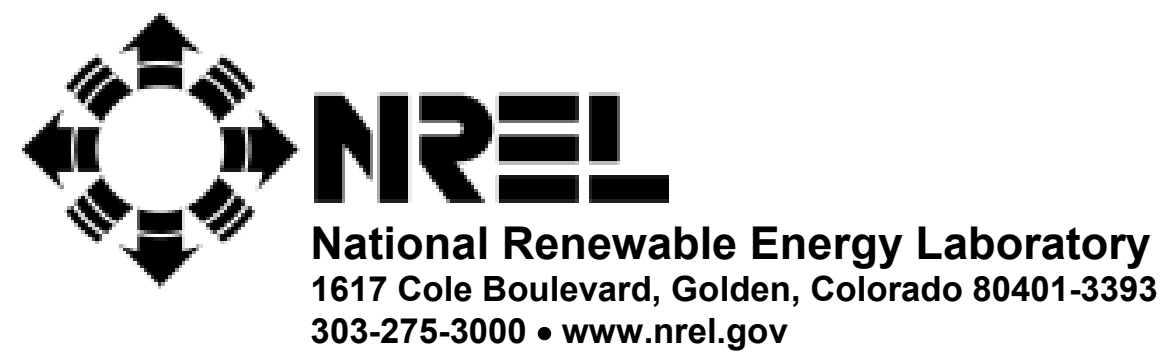

Operated for the U.S. Department of Energy Office of Energy Efficiency and Renewable Energy

by Midwest Research Institute • Battelle

Contract No. DE-AC36-99-G010337 


\section{NOTICE}

This report was prepared as an account of work sponsored by an agency of the United States government. Neither the United States government nor any agency thereof, nor any of their employees, makes any warranty, express or implied, or assumes any legal liability or responsibility for the accuracy, completeness, or usefulness of any information, apparatus, product, or process disclosed, or represents that its use would not infringe privately owned rights. Reference herein to any specific commercial product, process, or service by trade name, trademark, manufacturer, or otherwise does not necessarily constitute or imply its endorsement, recommendation, or favoring by the United States government or any agency thereof. The views and opinions of authors expressed herein do not necessarily state or reflect those of the United States government or any agency thereof.

Available electronically at http://www.osti.gov/bridge

Available for a processing fee to U.S. Department of Energy and its contractors, in paper, from:

U.S. Department of Energy

Office of Scientific and Technical Information

P.O. Box 62

Oak Ridge, TN 37831-0062

phone: 865.576 .8401

fax: 865.576 .5728

email: mailto:reports@adonis.osti.gov

Available for sale to the public, in paper, from:

U.S. Department of Commerce

National Technical Information Service

5285 Port Royal Road

Springfield, VA 22161

phone: 800.553 .6847

fax: 703.605.6900

email: orders@ntis.fedworld.gov

online ordering: http://www.ntis.gov/ordering.htm 


\section{Table of Contents}

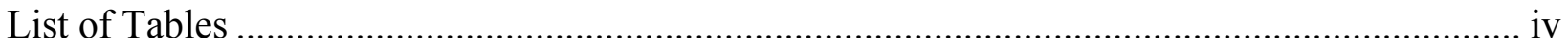

List of Figures ........................................................................................................... iv

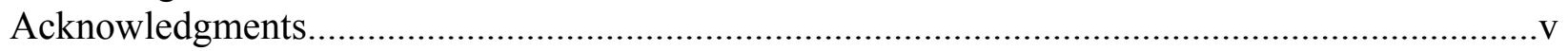

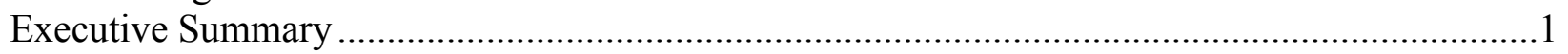

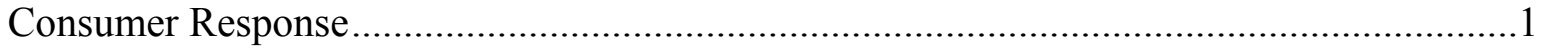

Renewable Energy Supplies ..................................................................................

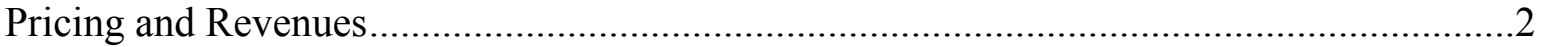

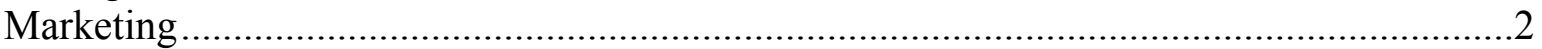

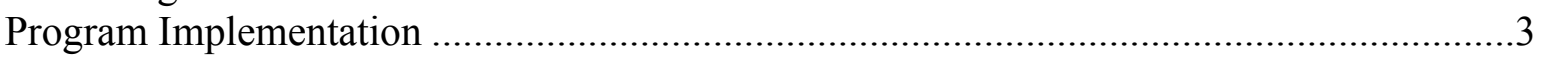

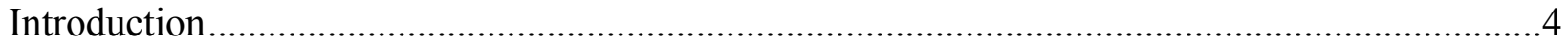

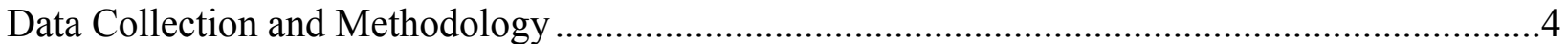

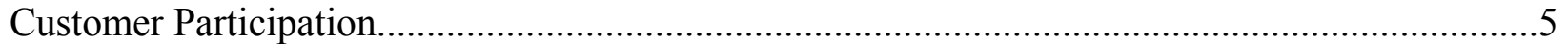

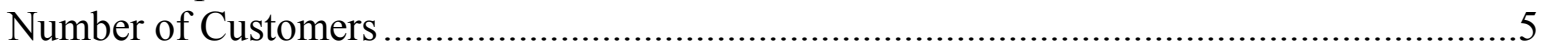

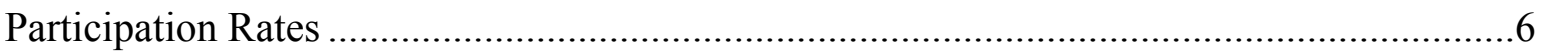

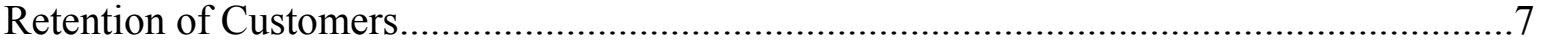

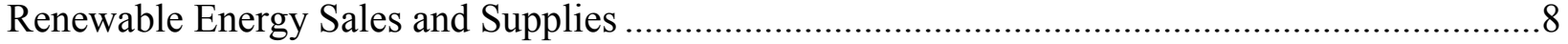

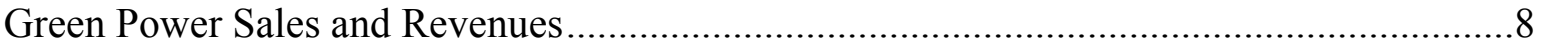

Green Energy Sales vs. Total Utility Sales ..................................................................

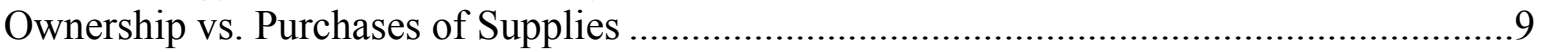

New Renewable Capacity Installations …………………..............................................10

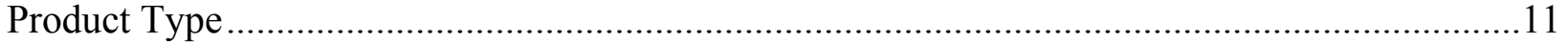

Energy Blocks vs. Percentage of Use ……………………........................................12

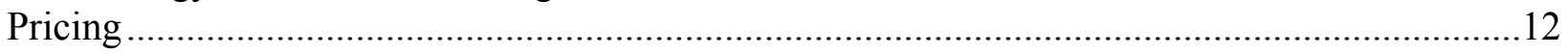

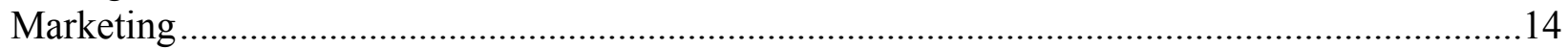

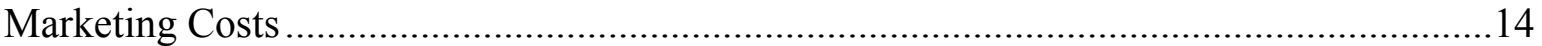

Marketing Techniques Employed ..................................................................................18

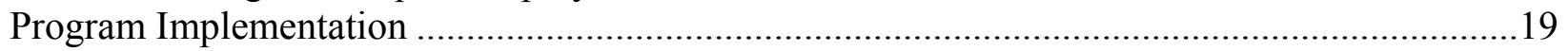

Enrollment Options ……………………………………........................................19

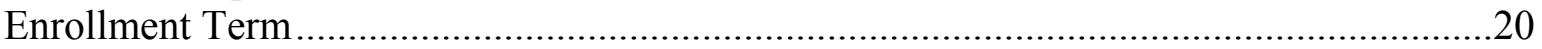

Program Evaluations and Market Research.....................................................................20

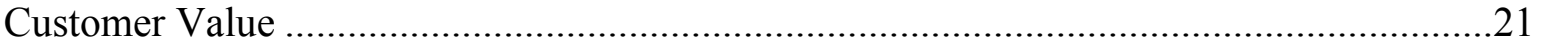

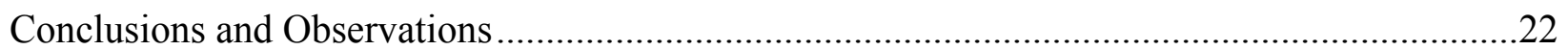

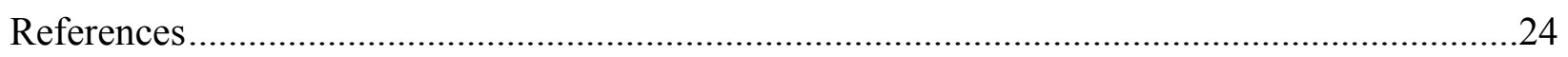

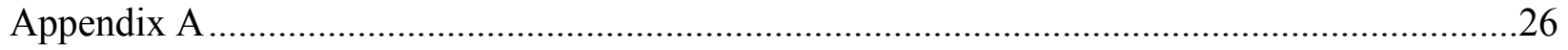

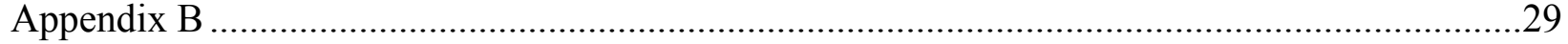

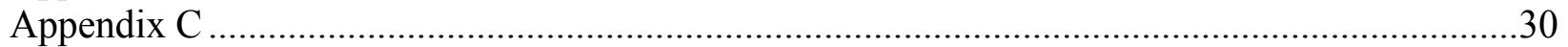




\section{List of Tables}

Table 1: Estimated Cumulative Number of Customers Participating in Utility Green Pricing Programs ................................................................................................

Table 2: Customer Participation Rates in Utility Green Pricing Programs ...................................6

Table 3: Average Participation Rate by Age of Green Pricing Programs (2003) ..........................

Table 4: Green Pricing Participation Rates by Utility Type (2003) ..........................................

Table 5: Annual Sales of Green Energy through Utility Green Pricing Programs........................8

Table 6: Green Energy Sales as a Percent of Total Utility Electricity Sales in kWh (2003) ........9

Table 7: Residential Expenditures Per Month and Annual Revenues (2002 and 2003) ...............9

Table 8: Utility Procurement of Renewable Energy Supplies (2003) ........................................9

Table 9: REC Purchases by Utilities to Supply Green Pricing Programs (2002 and 2003)........10

Table 10: New Renewables Capacity Supplying Green Pricing Programs (2003) ......................11

Table 11: Price Premiums of Utility Green Power Products........................................................13

Table 12: Green Pricing Premiums by Utility Type (2003) ………............................................14

Table 13: Residential Customer Acquisition Costs .................................................................15

Table 14: Annual Cost of Marketing and Program Administration by Size of Utility (2003)......16

Table 15: Annual Marketing and Administrative Costs per Customer by Size of Utility..............17

Table 16: Marketing and Administrative Expenditures as Percentage of Premium (2003) ..........17

Table 17: Explanation of Costs Born by Nonparticipants .......................................................18

Table 18: Marketing Strategies Used by Utilities .....................................................................19

Table 19: Number of Marketing Techniques Used by Utilities (2003).......................................19

Table 20: Methods of Enrolling in Green Pricing Programs ......................................................20

Table 21: Enrollment Term by Customer Segment..................................................................20

Table 22: Methods of Providing Additional Program Benefits.................................................22

Table B-1: Utilities Offering Green Pricing Programs in 2003 ................................................29

Table C-1: Green Pricing Program Renewable Energy Sales ...................................................30

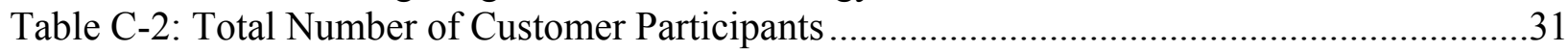

Table C-3: Customer Participation Rate ...................................................................................... 32

Table C-4: Price Premium Charged for New, Customer-Driven Renewable Power......................33

\section{List of Figures}

Figure 1: Annual and Cumulative Renewable Energy Capacity Installations To Serve Green Pricing Programs (Megawatts)

Figure 2: Types of Green Pricing Programs (2003)

Figure 3: Utility Green Pricing Program Premiums (2003) Energy-Based Programs Only .......13

Figure 4: Utility Reported Customer Acquisition Costs (2003)..................................................15 


\section{Acknowledgments}

This work was funded by the U.S. Department of Energy's (DOE) Office of Energy Efficiency and Renewable Energy (EERE). The authors wish to thank Linda Silverman, David McAndrew, and the technology programs of DOE for their support of this work. The authors also wish to thank Dan Lieberman of the Center for Resource Solutions, and Jørn Aabakken and Blair Swezey of NREL for their thoughtful review of the document, as well as Michelle Kubik of NREL for her editorial support. Finally, the authors wish to thank the many utility contacts that provided the information summarized in this report. Additional information on green power market trends and activities can be found on the U.S. DOE's Green Power Network Web site (http://www.eere.energy.gov/greenpower/). 


\section{Trends in Utility Green Pricing Programs (2003)}

\section{Executive Summary}

Utilities first began offering consumers a choice of purchasing electricity generated from renewable energy sources in the early 1990s. Since then, the number of U.S. utilities offering green pricing programs has steadily grown. Today, more than 500 utilities in regulated electricity markets — or about $16 \%$ of all utilities nationally-offer their customers green power options. Because some of these utilities offer programs in conjunction with cooperative associations or other public power entities, the number of distinct programs is slightly more than 100 . Through these programs, more than 33 million customers spanning 34 states have the ability to purchase renewable energy to meet some portion or all of their electricity needs, or make contributions to support the development of renewable energy resources. Typically, customers must pay a premium above standard electricity rates for this service.

This report presents year-end 2003 data on utility green pricing programs, and examines trends in consumer response and program implementation over time. The data provided in this report can be used by utilities as benchmarks by which to gauge the success of their green power programs.

At the end of 2003, about 520 megawatts (MW) of new renewable energy-based generation capacity was serving customers participating in utility green pricing programs, with another $170 \mathrm{MW}$ planned. Therefore, green pricing is proving to be a viable avenue for supporting the development of new renewable energy sources. However, current success can be attributed to a relatively small number of programs, thus the challenge going forward is to translate the success of these leading programs to the rest of the industry.

The following is a summary of key findings from this analysis.

\section{Consumer Response}

- About 265,000 customers were participating in a utility green pricing program at the end of 2003, which represents a 16\% increase from 2002 and nearly a fourfold increase from 1999. While more than 100 programs are available, just 10 programs are responsible for three-quarters of all participants.

- In 2003, sales of green energy through utility programs increased by more than $40 \%$ to 1.3 billion kilowatt-hours ( $\mathrm{kWh}$ ) annually. The growth in sales can be attributed to the greater number of customers purchasing green power-particularly new nonresidential customers - as well as larger purchases by customers. However, green pricing sales represent a small fraction of total utility electricity sales; on average, about $0.2 \%$ among all programs. As with participant numbers, sales figures are driven by a relatively small number of programs, with just 10 programs accounting for $85 \%$ of all sales, and one program accounting for nearly one-fourth of all sales.

- Customer participation rates have remained relatively steady in recent years, with an industry average of $1.2 \%$ and a median of $0.9 \%$. Programs that have been available 
for longer durations have achieved slightly higher penetration rates; for example, those that have been in existence for four or more years have average participation rates of nearly $2 \%$. The 10 most successful programs had participation rates between $4 \%$ and $11 \%$ in 2003 , compared to $3 \%$ to $6 \%$ in 2002 .

- The annual customer retention rate dropped slightly from an average of about $96 \%$ in 2002 to $93 \%$ in 2003 .

\section{Renewable Energy Supplies}

- More than one-third of utilities own the generation sources used to supply a significant portion of the energy sold through their green pricing programs, while the remainder purchase power or renewable energy certificates (RECs) from third parties.

- Utilities are showing greater interest in purchasing RECs to supply green pricing programs. In 2003, REC purchases represented about 33\% of all power sold through green pricing programs, compared to $11 \%$ in 2002.

- More than $520 \mathrm{MW}$ of new renewable capacity has been installed as a result of utility green pricing programs.

\section{Pricing and Revenues}

- The average premium for green power has declined by nearly $10 \%$ annually since 2000. In 2003, the median price premium — which had remained steady for several years-dropped by $20 \%$ to 2.0 cents per kilowatt-hour $(\varnothing / \mathrm{kWh})$. Premium reductions have been driven, in part, by lower-than-expected costs for renewable energy supplies, the availability of financial incentives, and narrowing cost spreads between renewables and natural gas-fired generation.

- About a half-dozen utilities offer fixed-price green power products or exempt their green power customers from some portion of fuel-cost charges. One program in particular has been extremely popular among nonresidential customers and is responsible for nearly one-fourth of all green pricing program sales nationwide.

- Green pricing premiums vary based on utility type, with investor-owned utilities (IOUs) charging an average premium of $3.4 \phi / \mathrm{kWh}$ compared to $2.3 \phi / \mathrm{kWh}$ for public utilities and cooperatives.

- Annual revenues from utility green pricing programs are estimated at $\$ 20$ million in 2003, an increase from \$15 million in 2002.

- Residential customers spent an average of about $\$ 5.50$ per month on green power during 2003, up from $\$ 4.80$ the previous year. This increase reflects the fact that residential consumers, on average, are purchasing more renewable energy through green pricing programs.

\section{Marketing}

- In 2003, utilities reported a median cost of acquiring new green pricing customers of approximately \$30. Large utilities generally reported higher customer-acquisition costs than small utilities; for example, the median for utilities serving more than 1 million customers was $\$ 46$, compared to $\$ 5$ for utilities with fewer than 100,000 customers. 
- Utilities spent a median of $5 \%$ (average $17 \%$ ) of the total green power premium charged on marketing and program administration, while the top performing programs spent a median of $30 \%$ (average $32 \%$ ).

- The top performing programs reported spending nearly $25 \%$ more on marketing and nearly $10 \%$ less on administration than all programs, on a per-customer basis.

- Bill inserts and utility newsletters are the most commonly used marketing strategies. Compared to all programs, the top performers are more likely to use direct mail, radio ads, events, newspaper ads, and telemarketing, but less likely to use television ads. In 2003, programs used an average of five different marketing techniques.

\section{Program Implementation}

- About one-third of programs have a minimum enrollment period for residential customers, while $44 \%$ of programs have a minimum requirement for nonresidential customers. The most common enrollment term is one year.

- Most utilities allow customers to enroll in the green pricing program by phone, at special events, by returning a mail-in card, or through the utility Web site. Fewer than $15 \%$ of utilities allow customers to enroll in the program by checking a box on their utility bills.

- Nearly two-thirds of utilities have conducted customer research to aid in the design of their green pricing program or to develop a marketing plan. Approximately $60 \%$ have conducted a program evaluation.

- The top performing programs were more likely to offer personal benefits to participants, such as newsletters with program updates, plaques or other types of recognition, protection from fuel-cost increases, discounts or promotions at local businesses, and decals for display in store windows. The top performers reported providing an average of four such benefits to participants, compared to an average of three for all programs. 


\section{Introduction}

Utilities first began offering consumers a choice of purchasing electricity generated from renewable energy sources in the early 1990s. Since then, the number of U.S. utilities offering green pricing programs has steadily grown. Today, more than 500 utilities in regulated electricity markets - or about $16 \%$ of all utilities nationally-offer their customers green power options. Because some of these utilities offer programs in conjunction with cooperative associations or other public power entities, the number of distinct programs is slightly more than 100 . Through these programs, more than 33 million customers spanning 34 states have the ability to purchase renewable energy to meet some portion or all of their electricity needs, or make contributions to support the development of renewable energy resources. Typically, customers must pay a premium above standard electricity rates for this service.

With a significant fraction of utilities now offering green power options to their customers, there is sufficient experience nationwide to assess industry trends and the potential contribution of these voluntary programs to overall renewable energy development. Since 1999, the National Renewable Energy Laboratory (NREL) has compiled data on utility green pricing programs on an annual basis. Initially, this data covered consumer response and program design features, such as participation and retention rates, price premiums, program structures, enrollment requirements, and new renewable energy capacity installed to supply green pricing programs. In 2002 and 2003, NREL added data on marketing and program implementation, covering areas such as customer acquisition costs, marketing strategies and budgets, program evaluation efforts, procurement of supplies, and methods of enrolling and providing value to customers. The 2002 data are presented in detail in Bird et al. (2004). This report presents data compiled for year-end 2003, and examines trends in consumer response and program implementation over time. The data provided in this report can also be used by utilities as a benchmark by which to gauge the success of their green power programs.

\section{Data Collection and Methodology}

The information presented in this report is based on data provided to the National Renewable Energy Laboratory (NREL) by utilities operating green pricing programs. In 2003, a questionnaire was distributed via e-mail to 93 green pricing program managers representing 102 green pricing programs (see Appendix $\mathbf{A}$ for the questionnaire, and Appendix B for a list of utilities that offer green pricing programs). For programs administered through a generation-and-transmission cooperative or a public power supplier, the questionnaire was typically distributed only to the power supplier, rather than to the participating distribution utilities. However, in some cases, the power supplier was not able to provide data on marketing and program implementation. Therefore, the authors did obtain data from a small number of municipal utilities and cooperatives that participate in jointly marketed programs for which contact information was available. Two programs were found to be inactive, which reduced the total number to 100. Responses were received for 60 programs, yielding an overall program response rate of $60 \%$. Where possible, data gaps were filled with information obtained from audits of 
utility green pricing programs, utility Web sites, follow-up phone calls, and published reports (Washington CTED and UTC 2002, 2003; Harris 2002, Etra 2003), as well as data received in previous years.

\section{Customer Participation}

\section{Number of Customers}

At the end of 2003, an estimated 265,000 customers were participating in utility green pricing programs nationally, including about 6,500 nonresidential customers. ${ }^{1}$ The top 10 utility programs ${ }^{2}$ accounted for $74 \%$ of all participants (Appendix C). Almost one-fourth of the residential and nonresidential participants in 2003 were new. From 1999 to 2003, the number of customers participating in utility green pricing programs increased almost fourfold.

Table 1 delineates residential and nonresidential customer participation over time. During 2003, the number of nonresidential customers participating in green pricing programs increased by $66 \%$, while participation among residential customers increased by $15 \%$. This may be explained, in part, by an increased emphasis on marketing to the commercial and industrial sector in recent years, while many early green pricing programs primarily targeted residential customers.

Table 1: Estimated Cumulative Number of Customers Participating in Utility Green Pricing Programs

\begin{tabular}{|l|c|c|c|c|c|}
\hline Customer Segment & $\mathbf{1 9 9 9}$ & $\mathbf{2 0 0 0}$ & \multicolumn{1}{c|}{$\mathbf{2 0 0 1}$} & \multicolumn{1}{c|}{$\mathbf{2 0 0 2}$} & \multicolumn{1}{c|}{$\mathbf{2 0 0 3}$} \\
\hline Residential & n/a* & 131,000 & 166,300 & 224,500 & 258,700 \\
\hline Nonresidential & n/a* & 1,700 & 2,500 & 3,900 & 6,500 \\
\hline Total & 66,900 & 132,700 & 168,800 & 228,400 & 265,000 \\
\hline$\%$ Nonresidential & n/a & $1.3 \%$ & $1.5 \%$ & $1.7 \%$ & $2.4 \%$ \\
\hline
\end{tabular}

*Information on customer segments was not collected in 1999.

In 2003, eight programs had sold all of the green power available under the program and were no longer actively seeking new customers - two of these programs maintained waiting lists. One utility indicated that nonresidential customers expressed interest in participating in its program, but there was not enough renewable energy available.

\footnotetext{
${ }^{1}$ NREL obtained consumer response data for about $70 \%$ of utility green pricing programs in 2003 , including all of the major programs. The remaining programs, which are smaller in size, do not have a large impact on overall participant numbers. Annual program participant numbers have been adjusted downward from those previously reported in Bird et al. (2004) because of program participation revisions made by the Los Angeles Department of Water and Power.

${ }^{2}$ NREL issues four different Top 10 lists based on total sales of renewable energy to program participants, total number of customer participants, customer participation rates, and the premium charged to support new renewables development.
} 


\section{Participation Rates}

At the end of 2003, the average rate of participation in green pricing programs among eligible utility customers was $1.2 \%$, with a median of $0.9 \%$ (Table 2 ); these industrywide rates have shown very little improvement in recent years. Some possible explanations include: 1) a general lack of awareness among customers, 2) lack of sustained marketing efforts on the part of some utilities, 3) a discrepancy between what customers report in surveys and what they actually do when presented with an option, 4) poor value propositions or product quality, 5) lack of commitment on the part of some utilities to expand programs when they become fully subscribed, and 6) the addition of new programs each year, which are averaged with the performance of more established programs (Holt and Holt, 2004; Swezey and Bird, 2001).

The Top 10 programs achieved participation rates of between $4 \%$ and $11 \%$ in 2003 , compared to $3 \%$ to $6 \%$ in 2002 (Appendix C). ${ }^{3}$ While average participation rates among the top programs have shown improvement, they remain well below penetration rates predicted by utility market research surveys (Farhar 1999).

Table 2: Customer Participation Rates in Utility Green Pricing Programs

\begin{tabular}{|l|c|c|c|c|c|}
\hline Participation Rate & $\mathbf{1 9 9 9}$ & $\mathbf{2 0 0 0}$ & $\mathbf{2 0 0 1}$ & $\mathbf{2 0 0 2}$ & $\mathbf{2 0 0 3}$ \\
\hline Average & $0.9 \%$ & $1.2 \%$ & $1.3 \%$ & $1.2 \%$ & $1.2 \%$ \\
\hline Median & $0.8 \%$ & $0.7 \%$ & $0.7 \%$ & $0.8 \%$ & $0.9 \%$ \\
\hline Top 10 programs & $2.1 \%-4.7 \%^{*}$ & $2.6 \%-7.3 \%$ & $3.0 \%-7.0 \%$ & $3.0 \%-5.8 \%$ & $3.9 \%-11.1 \%$ \\
\hline
\end{tabular}

*Data for April 2000

For those programs that have existed for one or more years, data show increasing rates of participation (Table 3). At the end of 2003, the average participation rate for programs that were at least four years old was $1.8 \%$, compared to $1.2 \%$ for all programs. When examining data for 2002 and earlier, Wiser et al. (2004) found a positive and statistically significant relationship between participation rates and program duration. They also found that program design, implementation, and marketing play a role in influencing participation rates. Based on these findings, it can be postulated that participation rates grow over time as customers become increasingly aware of green product offerings and utilities become more adept at product marketing.

Table 4 shows that across all utilities, the average participation rate in 2003 for residential customers was $1.4 \%$ but only $0.5 \%$ for nonresidential customers. Median participation rates were $1 \%$ and $0.2 \%$ for residential and nonresidential customers, respectively. The lower participation rates among nonresidential customers may be

\footnotetext{
${ }^{3}$ The high end of the range declined from 2000 to 2002 because the utility with the highest participation rate (Moorhead Public Service) experienced an increase in its overall customer base, while the number of participants in its green pricing program remained steady. The program was fully subscribed in 2000 , and the utility has not attempted to expand it.
} 
explained, in part, by the fact that some programs place less emphasis on the nonresidential sector. Also, nonresidential customers as a whole may be more pricesensitive and perhaps less willing to pay a premium than residential consumers.

Table 3: Average Participation Rate by Age of Green Pricing Programs (2003)

\begin{tabular}{|l|l|}
\hline All programs & $1.2 \%$ \\
\hline Programs at least 1 year old & $1.2 \%$ \\
\hline Programs at least 2 years old & $1.4 \%$ \\
\hline Programs at least 3 years old & $1.5 \%$ \\
\hline Programs at least 4 years old & $1.8 \%$ \\
\hline \multicolumn{2}{|l|}{ Note: Percentages based on 75 programs } \\
\hline
\end{tabular}

Table 4 also reveals differences in average participation rates among programs offered by IOUs, municipal or public utilities, and cooperatives; however, the differences narrow when the median rates are compared. Average participation rates were lowest among IOUs. However, caution is advised in drawing conclusions based on these data. For example, after performing a statistical analysis of 2002 data, Wiser et al. (2004) found no evidence that utility-ownership type influenced participation rates but did find that smaller utilities tend to achieve higher participation rates.

Table 4: Green Pricing Participation Rates by Utility Type (2003)

\begin{tabular}{|l|c|c|c|c|}
\hline Utility Type & $\begin{array}{c}\text { Number of } \\
\text { Programs }\end{array}$ & $\begin{array}{c}\text { Residential } \\
\text { Customers } \\
\text { Average/Median }\end{array}$ & $\begin{array}{c}\text { Nonresidential } \\
\text { Customers } \\
\text { Average/Median }\end{array}$ & $\begin{array}{c}\text { All Customers } \\
\text { Average/Median }\end{array}$ \\
\hline All Utilities & 75 & $1.4 \% / 1.0 \%$ & $0.5 \% / 0.2 \%$ & $1.2 \% / 0.9 \%$ \\
\hline Cooperatives & 13 & $1.7 \% / 1.1 \%$ & $0.6 \% / 0.007 \%$ & $1.6 \% / 1.0 \%$ \\
\hline Public & 36 & $1.5 \% / 1.1 \%$ & $0.5 \% / 0.2 \%$ & $1.3 \% / 1.0 \%$ \\
\hline Investor-owned & 26 & $1.0 \% / 0.9 \%$ & $0.3 \% / 0.1 \%$ & $0.8 \% / 0.7 \%$ \\
\hline
\end{tabular}

\section{Retention of Customers}

In 2003, utilities reported that an average of $7.1 \%$ and a median of $6.6 \%$ of customers dropped out of green pricing programs. In 2002, the average rate of attrition was $4.3 \%$, with a median of $2.5 \%$. Thus, the annual customer retention rate among programs declined slightly to about $93 \%$ in 2003 , from $96 \%$ or better in 2002 . No explanations of the increased attrition rates were offered. Historically, utilities that have reported higherthan-average turnover rates among green power customers cite high turnover among all utility customers; for example, several of these utilities have service territories that include large universities where high customer turnover is recurrent. One utility also cited particularly high attrition rates after announcing plans to build a new coal-fired power plant, which regional environmental organizations opposed. And a few utilities have 
experienced higher-than-average decreases in enrollment as a result of general rate increases. However, other utilities have reported steady enrollments in green power programs despite rate increases.

\section{Renewable Energy Sales and Supplies}

\section{Green Power Sales and Revenues}

Collectively, utilities sold about 1.3 billion kilowatt-hours (kWh), or 147 average megawatts (aMW), of green power to customers in 2003 (Table 5). Green power sales to all customer classes grew by $44 \%$ in 2003 , compared to $56 \%$ in 2002 and $26 \%$ in 2001 . The 10 top-performing green pricing programs represented $85 \%$ of total sales, with one program (Austin Energy) accounting for nearly one-quarter of all sales (Appendix C). The growth in sales can be attributed to the larger number of customers purchasing green power - particularly new nonresidential customers - as well as larger purchases by customers. Austin Energy's sales success stems from the fact that it allows customers to lock-in the price of green energy for up to 10 years, which has been particularly popular among nonresidential customers. Purchases by nonresidential customers represented nearly one-third of total sales in 2003 for all programs.

Table 5: Annual Sales of Green Energy through Utility Green Pricing Programs (millions of kWh)

\begin{tabular}{|l|c|c|c|c|}
\hline & $\mathbf{2 0 0 0}$ & $\mathbf{2 0 0 1}$ & $\mathbf{2 0 0 2}$ & $\mathbf{2 0 0 3}$ \\
\hline Residential customers & --- & 399.7 & 661.3 & 874.1 \\
\hline Nonresidential customers & --- & 172.8 & 233.7 & 410.3 \\
\hline All customers & 453.7 & 572.5 & 895.0 & $1,284.4$ \\
\hline$\%$ Nonresidential & --- & $30 \%$ & $26 \%$ & $32 \%$ \\
\hline * Sales information for customer segments not available for 2000. \\
\hline
\end{tabular}

\section{Green Energy Sales vs. Total Utility Sales}

Green energy sales still represent a small proportion of a utility company's overall energy sales. Table 6 shows that, on average, sales through green pricing programs represent about $0.2 \%$ of total utility electricity sales. Green power sales represent about $0.3 \%$ of residential electricity sales and $0.08 \%$ of nonresidential electricity sales. The most successful utility programs report green energy sales of about $3 \%$ of total electricity sales.

On average, residential customers spent $\$ 5.50$ per month to purchase or support green power through utility programs in 2003, up from $\$ 4.80$ in 2002 (Table 7). This increase reflects the fact that residential consumers, on average, are purchasing more renewable energy through green pricing programs. 
Table 6: Green Energy Sales as a Percent of Total Utility Electricity Sales in kWh (2003)

\begin{tabular}{|l|c|c|c|}
\hline & Average & Median & Range \\
\hline Residential customers & $0.32 \%$ & $0.02 \%$ & $0.00 \%-3.58 \%$ \\
\hline Nonresidential customers & $0.08 \%$ & $0.00 \%$ & $0.00 \%-2.86 \%$ \\
\hline All customers & $0.21 \%$ & $0.04 \%$ & $0.00 \%-3.15 \%$ \\
\hline
\end{tabular}

Utilities collected an estimated \$20 million in revenues from green power sales in 2003, up from \$15 million in 2002 (Table 7). Revenues increased at a slower rate than green power sales, indicating that programs with lower premiums may be selling more green energy. Green pricing program revenues are typically used to pay the above-market costs of renewables as well as the costs of administering and marketing the program, although the treatment of the latter differs by utility (see discussion below and Holt and Holt 2004; Swezey and Bird 2001).

Table 7: Residential Expenditures Per Month and Annual Revenues (2002 and 2003)

\begin{tabular}{|l|c|c|}
\hline & $\mathbf{2 0 0 2}$ & $\mathbf{2 0 0 3}$ \\
\hline Monthly residential customer expenditures on green power & $\$ 4.80$ & $\$ 5.50$ \\
\hline Annual utility revenues from green power & $\$ 15$ million & $\$ 20$ million \\
\hline
\end{tabular}

\section{Ownership vs. Purchases of Supplies}

About one-third of utilities supply their green pricing programs entirely from their own renewable energy generation facilities (Table 8). Another 50\% of utilities either purchase all of their power from an independent power generator or purchase renewable energy certificates (RECs) from a marketer or supplier. ${ }^{4}$ The remaining utilities use a combination of these approaches to supply their green power programs.

Table 8: Utility Procurement of Renewable Energy Supplies (2003)

\begin{tabular}{|l|c|c|c|c|c|c|}
\hline & \multicolumn{2}{|c|}{$\begin{array}{c}\text { Utilities that } \\
\text { Own } \\
\text { Generation }\end{array}$} & \multicolumn{2}{|c|}{$\begin{array}{c}\text { Utilities that } \\
\text { Purchase } \\
\text { Power }\end{array}$} & $\begin{array}{c}\text { Utilities that } \\
\text { Purchase } \\
\text { RECs }\end{array}$ \\
\hline $\begin{array}{l}\text { For } 100 \% \text { of program power } \\
\text { supplies }\end{array}$ & 23 & $31 \%$ & 24 & $32 \%$ & 13 & $18 \%$ \\
\hline $\begin{array}{l}\text { For at least } 50 \% \text { of program power } \\
\text { supplies }\end{array}$ & 29 & $39 \%$ & 31 & $42 \%$ & 15 & $20 \%$ \\
\hline $\begin{array}{l}\text { For any fraction of program power } \\
\text { supplies }\end{array}$ & 36 & $49 \%$ & 35 & $47 \%$ & 18 & $24 \%$ \\
\hline Note: Percentages based on 74 programs. & \multicolumn{7}{|l|}{} \\
\hline
\end{tabular}

\footnotetext{
${ }^{4}$ RECs represent the environmental attributes of renewable energy-generating facilities and can be sold separately from commodity electricity.
} 
The use of RECs in green pricing programs is a relatively recent development; prior to 2001, very few utilities purchased unbundled RECs. Collectively, utilities purchased about 420 million kWh of RECs to serve green power customers in 2003, which represents about one-third of all green power sold through utility green pricing programs (Table 9). The use of RECs by utilities to supply their green pricing programs increased more than fourfold from 2002 to 2003, suggesting that utilities are becoming more comfortable with this method of procuring renewable energy supplies. About threequarters of utilities that supply their programs with RECs are located in the Pacific Northwest.

Table 9: REC Purchases by Utilities to Supply Green Pricing Programs (2002 and 2003)

\begin{tabular}{|l|c|c|}
\hline & $\mathbf{2 0 0 2}$ & $\mathbf{2 0 0 3}$ \\
\hline REC purchases by utilities for green pricing programs & 102.6 million $\mathrm{kWh}$ & 419.4 million $\mathrm{kWh}$ \\
\hline REC purchases as percent of green pricing sales & $11 \%$ & $33 \%$ \\
\hline
\end{tabular}

\section{New Renewable Capacity Installations}

The amount of new renewable energy capacity installed to serve green pricing programs has grown significantly during the past several years (Figure 1). ${ }^{5}$ At the end of 2003, utilities had installed about $520 \mathrm{MW}$ of renewables capacity with another $170 \mathrm{MW}$ planned (Table 10). Wind, solar, and landfill gas are the renewable resources most commonly included in green pricing programs, with wind representing the largest portion of the total capacity - at the end of 2003 , wind energy represented more than $80 \%$ of the installed capacity.

While many programs use blends of renewable energy sources, more than half of all programs feature only one energy source. Among the more than 100 programs offered, 43 programs use only wind, nine use only solar, and seven use only biomass. The remaining programs offer a blend of two or more resources.

\footnotetext{
${ }^{5}$ The timing of capacity installations in the more recent years has been influenced by the availability of the federal production tax credit (PTC) for wind energy facilities. As with wind energy installations generally, more capacity has been installed in years when the PTC was scheduled to expire $(1999,2001$, and 2003) as developers have rushed to complete projects. Development has lagged in the interim years because of the uncertainty surrounding the PTC extension and the lead times necessary to plan and complete projects. This explains the relatively small amount of capacity installed in 2000 and 2002, compared to capacity additions in 2001 and 2003.
} 


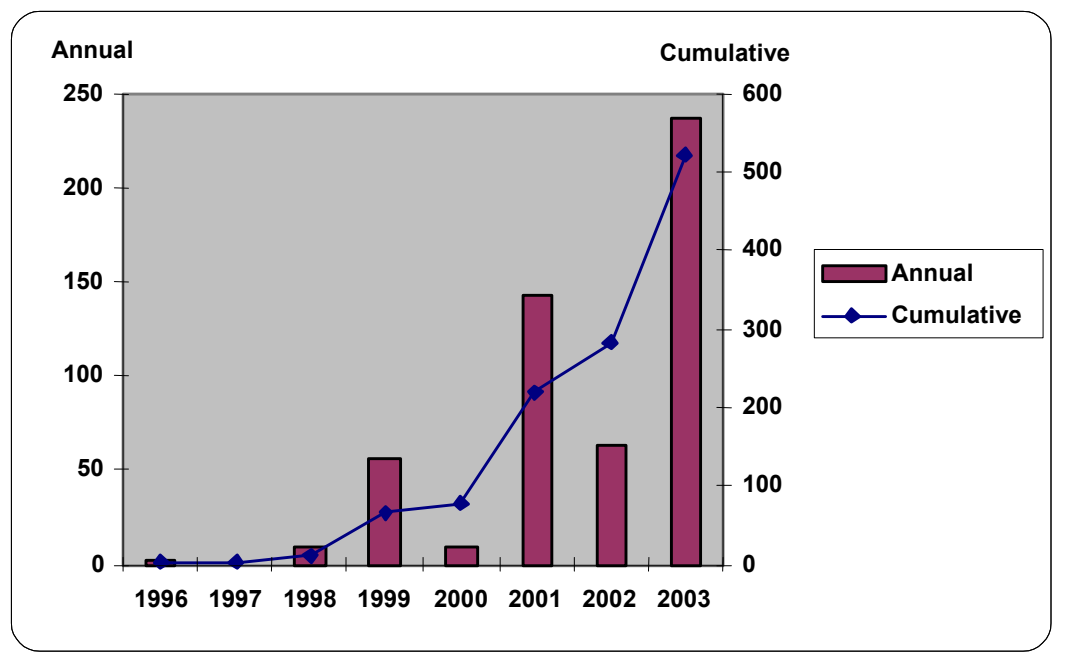

Source: Bird and Swezey 2004

Figure 1: Annual and Cumulative Renewable Energy Capacity Installations To Serve Green Pricing Programs (Megawatts)

Table 10: New Renewables Capacity Supplying Green Pricing Programs (2003) (Megawatts)

\begin{tabular}{|l|r|r|r|r|}
\hline Source & \multicolumn{2}{|c|}{ Installed } & \multicolumn{2}{c|}{ Planned } \\
\hline Wind & 425.4 & $81.7 \%$ & 133.4 & $78.6 \%$ \\
\hline Biomass & 75.7 & $14.5 \%$ & 10.0 & $5.9 \%$ \\
\hline Solar & 4.9 & $0.9 \%$ & 1.3 & $0.8 \%$ \\
\hline Geothermal & 5.5 & $1.1 \%$ & 25.0 & $14.7 \%$ \\
\hline Small Hydro & 9.3 & $1.8 \%$ & 0.0 & $0.0 \%$ \\
\hline Total & 520.8 & $100.0 \%$ & 169.7 & $100.0 \%$ \\
\hline
\end{tabular}

Source: Bird and Swezey 2004

\section{Product Type}

Most utility green pricing programs are structured so that customers can purchase renewable energy to meet some or all of their electricity needs. The green power premium charged in these "energy-based" programs is typically expressed in $\notin / \mathrm{kWh}$ or $\$ / \mathrm{kWh}$ block. Most of the top-performing green pricing programs are energy-based. Other programs are structured to allow customers to contribute funds that support the development of renewable energy sources. These so-called "contribution programs" have become less common, and currently represent only 12\% of all programs (Figure 2). Finally, a few utilities have offered programs through which customers make a monthly payment tied to the amount of renewable energy capacity that is supported ("capacitybased programs"). For example, customers might be offered the option to pay $\$ 6$ each month to support 100 watts of solar energy generating capacity. Capacity-based programs are no longer actively marketed and, in some cases, are being phased out in favor of energy-based programs. 


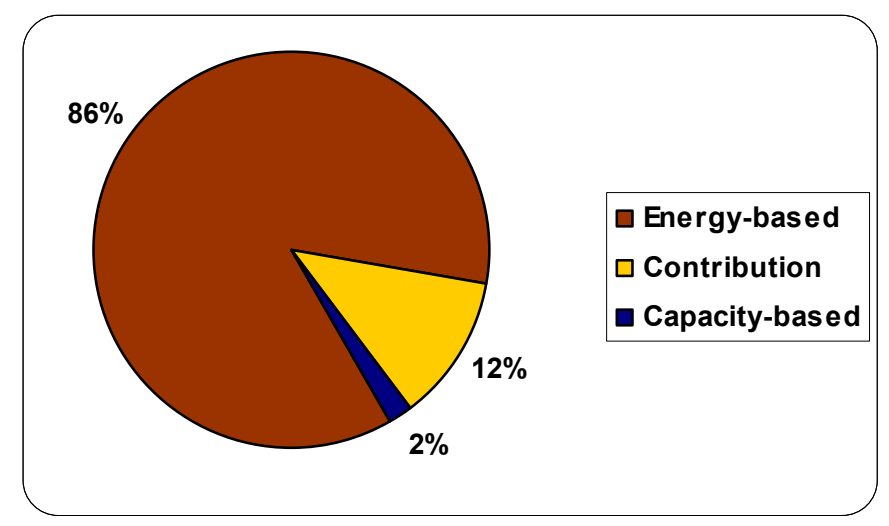

Figure 2: Types of Green Pricing Programs (2003)

\section{Energy Blocks vs. Percentage of Use}

About two-thirds of energy-based programs are structured so that customers can purchase blocks of green power. Block sizes range from $15 \mathrm{kWh}$ for energy derived exclusively from solar systems to $1,000 \mathrm{kWh}$ for energy derived from a blend of new wind sources and existing renewables. The most common block size offered to residential customers is $100 \mathrm{kWh}$. Many utilities offer larger block sizes to nonresidential customers and some offer customers the option of purchasing green power for all of the electricity they use.

The remaining programs allow customers to purchase green power for some fraction of their electricity needs. Most of these programs allow residential customers to elect to have $25 \%, 50 \%$, or $100 \%$ of their electricity come from renewable sources, while a few offer fractions as small as 10\%. Often, commercial and industrial customers can purchase green power for a smaller fraction of their electricity use.

\section{Pricing}

In 2003, price premiums for energy-based programs ranged from $0.6 \notin / \mathrm{kWh}$ to $17.6 \phi / \mathrm{kWh}$, with an average premium of $2.62 \phi / \mathrm{kWh}$ and a median of $2.00 \phi / \mathrm{kWh}$.

Figure 3 displays price premiums for individual utility programs-solar-only products dominate the high end of the price range. In 2003, the 10 programs with the lowest premiums for energy derived from new renewable sources had premiums ranging from $0.6 \phi / \mathrm{kWh}$ to $1.3 \phi / \mathrm{kWh}$.

Since 2000, the average price premium has dropped at an average rate of nearly $10 \%$ annually. The median premium, which had remained relatively constant at $2.5 \varnothing$ from 2000 to 2002, declined by 20\% in 2003 (Table 11). During 2003, 10 programs changed the premium charged for green power, with eight reporting a premium decrease. Most of the utilities attributed the reduction to lower-than-expected costs for renewable energy supplies (e.g., higher capacity factors than expected). Other reasons that have contributed to the decline in premiums over time are the availability of state or federal financial incentives and natural gas price increases, which have reduced the cost spread between renewable energy and gas-fired generation. 


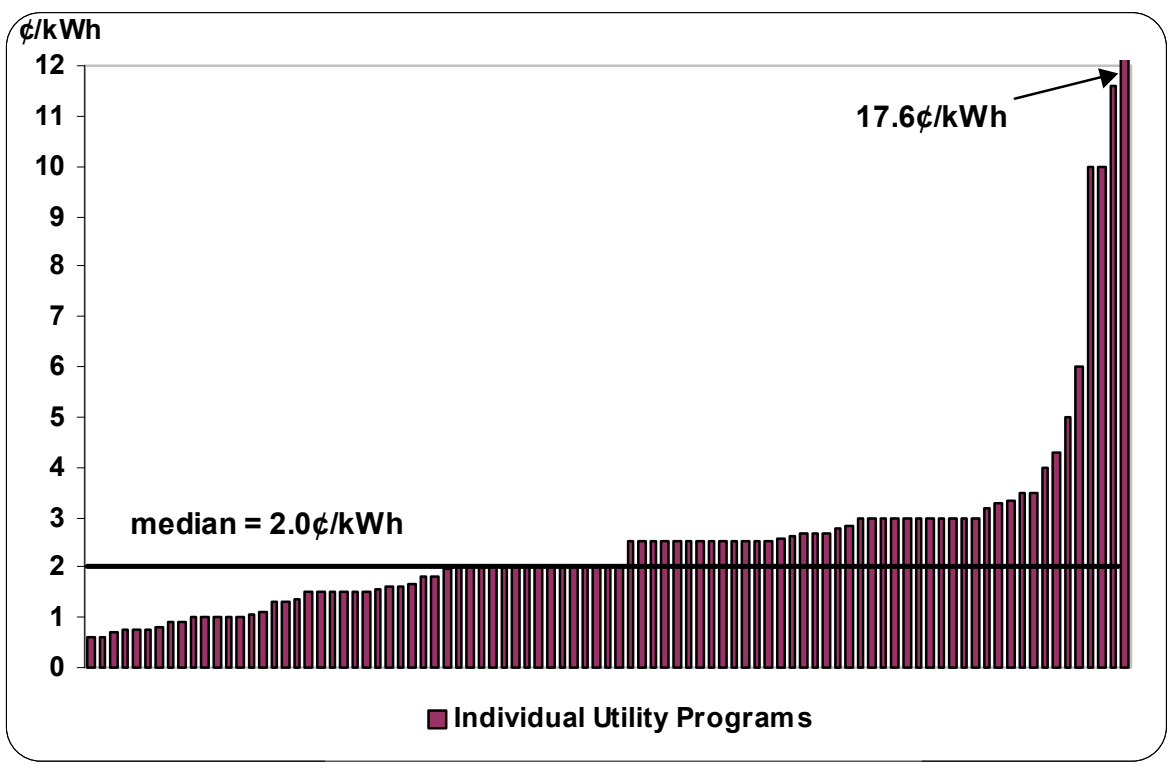

Figure 3: Utility Green Pricing Program Premiums (2003) Energy-Based Programs Only

Table 11: Price Premiums of Utility Green Power Products $(\phi / k W h)$

\begin{tabular}{|c|c|c|c|c|c|}
\hline & 1999 & 2000 & 2001 & 2002 & 2003 \\
\hline Average Premium & 2.15 & 3.48 & 2.93 & 2.82 & 2.62 \\
\hline Median Premium & 2.00 & 2.50 & 2.50 & 2.50 & 2.00 \\
\hline Range of Premiums & $0.4-5.0$ & $(0.5)-20.0$ & $0.9-17.6$ & $0.7-17.6$ & $0.6-17.6$ \\
\hline 10 Programs with Lowest Premiums* & $0.4-2.5^{* *}$ & $(0.5)-2.5$ & $1.0-1.5$ & $0.7-1.5$ & $0.6-1.3$ \\
\hline Number of Programs Represented & 24 & 50 & 60 & 80 & 91 \\
\hline \multicolumn{6}{|c|}{$\begin{array}{l}{ }^{*} \text { Represents the } 10 \text { utility programs with the lowest price premiums for new customer-driven renewable energy. This includes only } \\
\text { programs that have installed }- \text { or announced firm plans to install or purchase power from }- \text { new renewable energy sources. In } \\
2001 \text { the discrepancy between the low end of the range for all programs and the Top } 10 \text { programs results from the fact that the } \\
\text { program with the lowest premium }(0.9 \phi / k W h) \text { was not eligible for the Top } 10 \text { because it was either selling some existing } \\
\text { renewables or had not installed any new renewable capacity for its program. }\end{array}$} \\
\hline
\end{tabular}

Table 12 presents green pricing premiums by utility type. Investor-owned utilities have the highest average price premium $(3.4 \phi / \mathrm{kWh})$, while public and cooperative utilities have lower average premiums $(2.3 \notin / \mathrm{kWh})$. Public utilities have the lowest median premium $(2.0 \notin / \mathrm{kWh})$. Some of the differences among utility types may result from a greater tendency of IOUs to include program administration and marketing costs in the premium, or to seek recovery of program costs over a shorter period of time. The higher average premium calculated for investor-owned utilities may also stem from the fact that several IOUs offer solar-only programs with relatively high premiums, on the order of $10 \notin / \mathrm{kWh}$ or higher. 
Table 12: Green Pricing Premiums by Utility Type (2003) $(\phi / k W h)$

\begin{tabular}{|l|c|c|c|}
\hline Type of Utility & Average & Median & Range \\
\hline Investor-owned & 3.36 & 2.04 & $0.63-17.6$ \\
\hline Public & 2.30 & 2.00 & $0.60-11.6$ \\
\hline Cooperative & 2.34 & 2.50 & $0.90-3.50$ \\
\hline All Utilities & 2.62 & 2.00 & $0.60-17.6$ \\
\hline
\end{tabular}

A half a dozen programs differentiate the premium charged for nonresidential and residential participants. Most of these programs offer lower green energy premiums to nonresidential customers, essentially offering bulk purchase discounts for large green power purchasers. These premiums charged to nonresidential customers range from $1 \phi / \mathrm{kWh}$ to $4.5 \phi / \mathrm{kWh}$ less than the residential green energy premium. Two programs offer a separate green power product to large purchases at lower premiums than their residential offerings. Another program charges nonresidential customers a higher premium (approximately $1 \phi / \mathrm{kWh}$ higher) for green energy, because their standard electricity rates are lower.

Because most renewable energy facilities do not rely on fuel, some utilities offer fixedprice green power products or exempt their green power customers from some fuel-cost charges. Seven utilities include this feature as a component of their green pricing product. ${ }^{6}$ One of these utilities also exempts green power customers from the costs associated with making environmental improvements at some of its fossil fuel-generating facilities. Exempting customers from fossil fuel costs can be a particularly important strategy for enrolling nonresidential customers, as evidenced by the success of Austin Energy, which accounts for about $25 \%$ of all utility green pricing sales.

\section{Marketing}

\section{Marketing Costs}

One measure of the cost of marketing a green pricing program is customer-acquisition cost - the amount of funds spent on marketing, divided by the number of new customers that enroll in the program. For 2003, utilities providing this data reported median and average residential customer-acquisition costs for green pricing programs of $\$ 31$ and $\$ 36$, respectively (Table 13). ${ }^{7}$ However, the responses varied widely, ranging from $\$ 0$ to $\$ 125$ (Figure 4). The top performing programs reported median and average residential customer-acquisition costs of $\$ 40$ and $\$ 48$, respectively.

\footnotetext{
${ }^{6}$ Based on data reported in 2002 and 2003, the seven utilities offering fuel-price stability are: Alliant Energy, Austin Energy, Eugene Water \& Electric Board, Madison Gas and Electric, Otter Tail Power, We Energies, and Xcel Energy (Colorado program only).

${ }^{7}$ Only about half of the utilities provided this information. The relative lack of responses may be because some utilities do not track customer-acquisition costs carefully.
} 
Table 13: Residential Customer-Acquisition Costs

\begin{tabular}{|l|c|c|c|c|c|c|}
\hline Type of Utility & $\begin{array}{c}\mathbf{2 0 0 2} \\
\text { Average }\end{array}$ & $\begin{array}{c}\mathbf{2 0 0 2} \\
\text { Median }\end{array}$ & $\begin{array}{c}\mathbf{2 0 0 2} \\
\text { Responses }\end{array}$ & $\begin{array}{c}\mathbf{2 0 0 3} \\
\text { Average }\end{array}$ & $\begin{array}{c}\mathbf{2 0 0 3} \\
\text { Median }\end{array}$ & $\begin{array}{c}\mathbf{2 0 0 3} \\
\text { Responses }\end{array}$ \\
\hline $\begin{array}{l}\text { 1-99.9K } \\
\text { Customers }\end{array}$ & $\$ 33$ & $\$ 15$ & 11 & $\$ 10$ & $\$ 5$ & 7 \\
\hline $\begin{array}{l}100 \mathrm{~K}-499.9 \mathrm{~K} \\
\text { Customers }\end{array}$ & $\$ 35$ & $\$ 33$ & 8 & $\$ 46$ & $\$ 40$ & 7 \\
\hline $\begin{array}{l}500 \mathrm{~K}-999.9 \mathrm{~K} \\
\text { Customers }\end{array}$ & $\$ 79$ & $\$ 71$ & 5 & $\$ 44$ & $\$ 38$ & 4 \\
\hline 1M+ Customers & $\$ 72$ & $\$ 72$ & 1 & $\$ 57$ & $\$ 46$ & 4 \\
\hline All Utilities & $\$ 44$ & $\$ 30$ & 25 & $\$ 36$ & $\$ 31$ & 22 \\
\hline
\end{tabular}

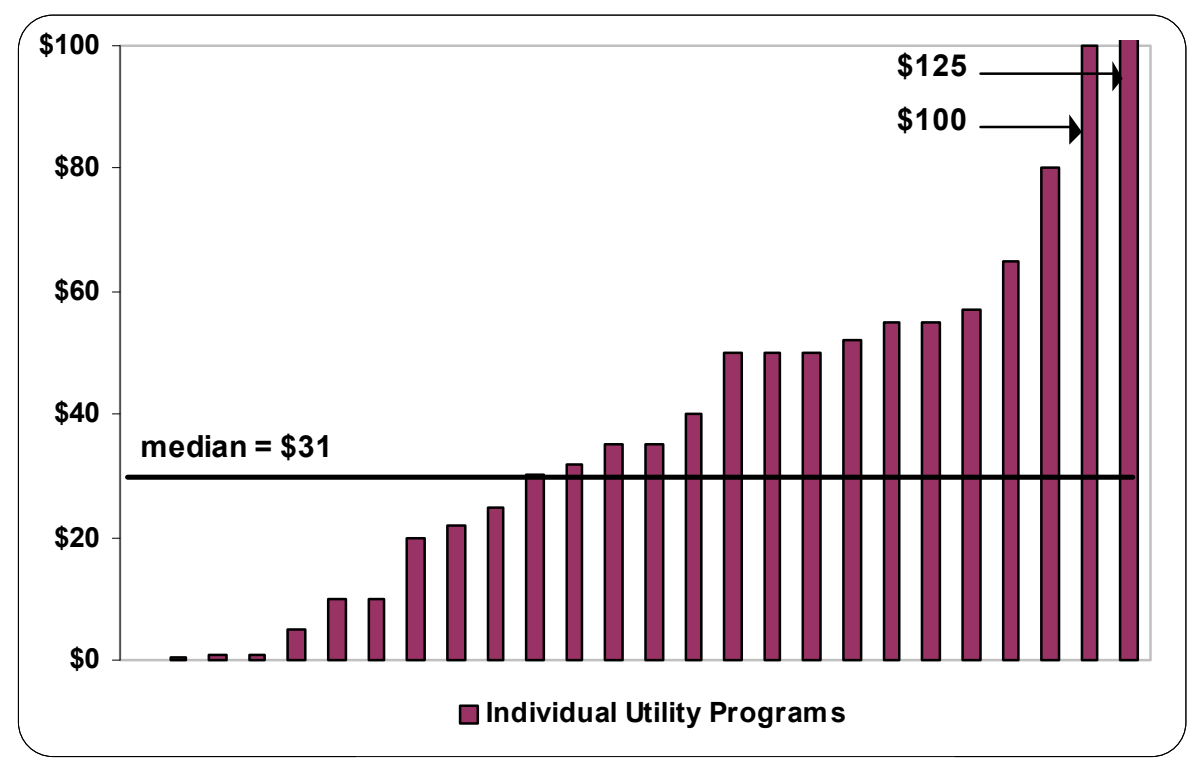

Figure 4: Utility-Reported Customer-Acquisition Costs (2003)

Customer-acquisition costs differed considerably depending on the size of the utility, with larger utilities generally reporting higher customer-acquisition costs than smaller utilities. For example, utilities with 1 million or more customers report a median customer acquisition cost of $\$ 46$ (average $\$ 57$ ), while utilities with fewer than 100,000 customers report a median of $\$ 5$ (average $\$ 10$ ) per customer acquired. Some of the variability may be due to the types of costs that the utilities included in the calculation. For example, some utilities do not attribute all of the costs of marketing and administration to the program, which would lead to lower per-customer costs. Small public or cooperative utilities may be more likely to share some of the program costs among all ratepayers than large, IOUs, which could explain some of the difference. Furthermore, large utilities may have the resources to track expenditures more closely.

Customer-acquisition costs can also vary over time, depending on the amount of marketing conducted. While average customer-acquisition costs decreased from $\$ 44$ to 
$\$ 36$ between 2002 and 2003, median costs remained nearly the same. Given the small number of utilities that reported this information (fewer than half of all respondents), caution should be used when inferring definitive trends or relationships based on these data.

In 2003 , utilities reported spending an average of $\$ 94,000$ (median $\$ 16,000$ ) on marketing their green pricing programs (excluding staff time), with responses varying widely by size of utility (Table 14). The largest companies (serving 1 million or more customers) spent an average of $\$ 388,000$ on marketing, while the smallest companies (serving fewer than 100,000 customers) spent an average of $\$ 17,000$ per year. Regarding program administration, the largest companies reported spending $\$ 275,000$ annually ( $\$ 87,000$ median) including staff time, while the smallest companies spent an average of $\$ 6,000$ per year ( $\$ 500$ median). Note that the range in administrative costs is smaller, especially when considering the median values.

Table 14: Annual Cost of Marketing and Program Administration by Size of Utility (2003)

\begin{tabular}{|l|c|c|c|c|}
\hline Utility Size & $\begin{array}{c}\text { Marketing } \\
\text { Excluding Staff Time) } \\
\text { Average/Median }\end{array}$ & Responses & $\begin{array}{c}\text { Program Administration } \\
\text { (Including Staff Time) } \\
\text { Average/Median }\end{array}$ & Responses \\
\hline $\begin{array}{l}1-99.9 K \\
\text { Customers }\end{array}$ & $\$ 17,000 / \$ 3,000$ & 18 & $\$ 6,000 / \$ 500$ & 7 \\
\hline $\begin{array}{l}100 K-499.9 K \\
\text { Customers }\end{array}$ & $\$ 46,000 / \$ 30,000$ & 16 & $\$ 64,000 / \$ 30,000$ & 10 \\
\hline $\begin{array}{l}500 K-999.9 K \\
\text { Customers }\end{array}$ & $\$ 227,000 / \$ 250,000$ & 5 & $\$ 114,000 / \$ 70,000$ & 4 \\
\hline $\begin{array}{l}1 \mathrm{M}+ \\
\text { Customers }\end{array}$ & $\$ 388,000 / \$ 350,000$ & 5 & $\$ 275,000 / \$ 87,000$ & 5 \\
\hline All Utilities & $\$ 94,000 / \$ 16,000$ & 44 & $\$ 97,000 / \$ 23,000$ & 26 \\
\hline
\end{tabular}

To adjust for differences in the size of the utilities, Table 15 reports annual marketing and administrative costs, divided by the number of utility customers (not just those participating in the program). Utilities reported spending an average of $29 \notin$ /customer (median 12 cents) on marketing, excluding staff time and $14 \phi /$ customer (median 5 cents) on administration including staff time. In general, larger companies appear to spend more on program administration per customer than smaller companies. Small utilities may not track all costs as closely, which could account for some of this difference. On average, the top performing programs spend about $35 \phi /$ customer on marketing, which is $23 \%$ more than the average for all programs. In addition, the top performing programs spend an average of about $13 \phi /$ customer on administration, which is nearly $10 \%$ less than the industry average. 
Table 15: Annual Marketing and Administrative Costs per Customer by Size of Utility

\begin{tabular}{|l|c|c|c|c|}
\hline Utility Size & $\begin{array}{c}\text { Marketing Costs per } \\
\text { Customer } \\
\text { Average/Median }\end{array}$ & Responses & $\begin{array}{c}\text { Program Administration } \\
\text { Costs per Customer } \\
\text { Average/Median }\end{array}$ & Responses \\
\hline $\begin{array}{l}1-99.9 K \\
\text { Customers }\end{array}$ & $38.8 \phi / 12.7 \phi$ & 16 & $8.4 \phi / 3.6 \phi$ & 9 \\
\hline $\begin{array}{l}100 K-499.9 K \\
\text { Customers }\end{array}$ & $18.7 \phi / 9.2 \phi$ & 16 & $17.0 \phi / 6.2 \phi$ & 11 \\
\hline $\begin{array}{l}500 K-999.9 K \\
\text { Customers }\end{array}$ & $32.0 \phi / 46.9 \phi$ & 5 & $19.3 \phi / 9.2 \phi$ & 4 \\
\hline $\begin{array}{l}1 \mathrm{M}+ \\
\text { Customers }\end{array}$ & $23.7 \phi / 13.6 \phi$ & 5 & $15.2 \phi / 3.4 \phi$ & 5 \\
\hline All Utilities & $28.5 \phi / 11.6 \phi$ & 42 & $14.3 \phi / 4.5 \phi$ & 29 \\
\hline
\end{tabular}

In 2003, utilities reported that a median of 5\% (average of 17\%) of the total green power premium was spent on marketing and program administration (Table 16), ${ }^{8}$ while the top performing programs reported spending a median of $30 \%$ and an average of $32 \%$.

Fifty programs (38\%) indicated that program participants cover all costs associated with the green pricing program. Of the remaining $62 \%$ of programs in which nonparticipants cover some costs, most program managers explained that some marketing and administrative costs were not attributed to the program (i.e., spread among all ratepayers). The other most commonly cited reasons were that the green pricing program received grants or other contributions, and that the utility spread the cost of unsold renewable energy among all ratepayers (Table 17).

Table 16: Marketing and Administrative Expenditures as Percentage of Premium (2003)

\begin{tabular}{|l|c|c|c|}
\hline & Average & Median & Responses \\
\hline $\begin{array}{l}\text { Fraction of green pricing premium devoted to } \\
\text { marketing and administration }\end{array}$ & $16.6 \%$ & $5.0 \%$ & 36 \\
\hline
\end{tabular}

\footnotetext{
${ }^{8}$ In 2002 , utilities reported spending an average of $20 \%$ (median $15 \%$ ) of their program budgets on marketing. It is not possible to compare responses for 2002 and 2003, because the questions differed.
} 
Table 17: Explanation of Costs Born by Nonparticipants

\begin{tabular}{|l|c|}
\hline Reason & Number of Responses \\
\hline $\begin{array}{l}\text { Some marketing and administrative costs are shared by all ratepayers (or not } \\
\text { attributed to the green pricing program) }\end{array}$ & 15 \\
\hline The program receives grants, subsidies, or other contributions & 5 \\
\hline The utility spreads the cost of unsold renewable energy among all ratepayers & 3 \\
\hline 43 programs responded, and 31 programs provided explanations; not all reasons are accounted for in this table. \\
\hline
\end{tabular}

\section{Marketing Techniques Employed}

In 2002 and 2003, utility green pricing program managers were asked to list the various marketing techniques applied to their green pricing program in the current year (Table 18). As in 2002, advertising programs through utility newsletters, bill inserts, and news articles or other publicity were among the top marketing strategies used in $2003 .{ }^{9}$ In fact, all of the various methods were listed in about the same relative order of use, except for events. Events were not listed as a specific option in the 2003 questionnaire, which may explain its low occurrence. It is also noteworthy that, in almost all instances, the fraction of utilities using each marketing strategy increased between 2002 and 2003. On average, utilities employed about five of the strategies (median of four) listed in the questionnaire. Only one-third of utilities employed three or fewer techniques (Table 19).

Other marketing strategies reported by utilities—but not listed in the questionnaire-were partnerships with sports teams or other organizations (reported by 5 utilities), Web site/online ads (4), signage and bumper stickers (3), newspaper inserts (1), direct sales to commercial accounts (1), messages on the utility bill itself (1), tours (1), contests (1), printed ads (1), annual meetings (1), radio talk shows (1), point-of-purchase displays (1), coupon books (1), trade shows (1), and conference sponsorships (1).

In general, a larger fraction of the top performing programs use the marketing techniques listed in Table 18, compared to all programs. For example, $66 \%$ of the top performers use direct mail compared to $48 \%$ of all programs in 2003 . The top performers were also more likely to use radio ads, events, newspaper ads, and telemarketing, but less likely to use television ads. The top performers reported using an average of 5 of the marketing techniques listed, which is the same as for all programs.

\footnotetext{
${ }^{9}$ Lieberman 2002 reviewed marketing data for public utilities with similar findings, except that direct mail was ranked higher.
} 
Table 18: Marketing Strategies Used by Utilities

\begin{tabular}{|c|c|c|c|}
\hline Marketing Technique & $\begin{array}{l}\text { Programs Using } \\
\text { Technique in } 2002\end{array}$ & $\begin{array}{l}\text { Programs Using } \\
\text { Technique in } 2003\end{array}$ & $\begin{array}{l}\text { Top Performers } \\
\text { Using Technique } \\
\text { in } 2003^{* *}\end{array}$ \\
\hline Bill inserts & $60.5 \%$ & $82.8 \%$ & $86.7 \%$ \\
\hline Utility newsletter & $70.0 \%$ & $81.0 \%$ & $86.7 \%$ \\
\hline Publicity & $63.3 \%$ & $63.8 \%$ & $66.7 \%$ \\
\hline Newspaper ads & $43.3 \%$ & $53.4 \%$ & $60.0 \%$ \\
\hline Direct mail & $55.0 \%$ & $48.3 \%$ & $66.7 \%$ \\
\hline Radio ads & $36.7 \%$ & $44.8 \%$ & $53.3 \%$ \\
\hline Other & $31.7 \%$ & $41.4 \%$ & $60.0 \%$ \\
\hline Events* & $80.0 \%$ & $24.1 \%$ & $40.0 \%$ \\
\hline Television ads & $20.0 \%$ & $22.4 \%$ & $13.3 \%$ \\
\hline Telemarketing & $8.3 \%$ & $13.8 \%$ & $20.0 \%$ \\
\hline Billboards & $6.7 \%$ & $6.9 \%$ & $6.7 \%$ \\
\hline
\end{tabular}

Table 19: Number of Marketing Techniques Used by Utilities (2003)

\begin{tabular}{|l|c|c|}
\hline & Number of Utilities & Percentage of Utilities \\
\hline Used 0-1 marketing techniques & 4 & $7 \%$ \\
\hline Used 2-3 marketing techniques & 15 & $26 \%$ \\
\hline Used 4-6 marketing techniques & 26 & $45 \%$ \\
\hline Used 7-9 marketing techniques & 12 & $21 \%$ \\
\hline 58 programs answered this question.
\end{tabular}

\section{Program Implementation}

\section{Enrollment Options}

Utilities reported that the most common methods for enrolling customers in green pricing programs included by phone through the utility's call center, during special events, via mail-in cards, and via the utility's Web site. Unlike in 2002, enrollment via the utility's Web site is now ranked almost equal to the other top three modes of enrollment; this may mean that customers are getting more accustomed to finding utility resources on the Internet. Only about $12 \%$ of utilities allowed customers to enroll by checking a box on their utility bills. Other methods listed included enrolling customers at retail partners or at the utility itself (reported by 4 utilities), enrolling via e-mail (3), newspaper advertisements and inserts (2), direct sales with account representative (1), and phone marketing by a contractor (1). On average, utilities offered four of the six enrollment options listed in the questionnaire (Table 20). 
Table 20: Methods of Enrolling in Green Pricing Programs

\begin{tabular}{|l|c|c|c|c|}
\hline & $\begin{array}{c}\text { Positive } \\
\text { Responses } \\
\mathbf{2 0 0 2}\end{array}$ & $\mathbf{\%}$ & $\begin{array}{c}\text { Positive } \\
\text { Responses } \\
\mathbf{2 0 0 3}\end{array}$ & $\mathbf{\%}$ \\
\hline Phone (through utility call center) & 57 & $91.9 \%$ & 51 & $86.4 \%$ \\
\hline Enroll at special events & 56 & $90.3 \%$ & 50 & $84.7 \%$ \\
\hline Returning mail-in card & 56 & $90.3 \%$ & 50 & $84.7 \%$ \\
\hline Utility Web site & 46 & $74.2 \%$ & 49 & $83.1 \%$ \\
\hline Other & 14 & $22.6 \%$ & 18 & $30.5 \%$ \\
\hline Check-box on utility bill & 5 & $8.1 \%$ & 7 & $11.9 \%$ \\
\hline Note: The number of respondents in 2002 was 62 and 59 in 2003. \\
\hline
\end{tabular}

\section{Enrollment Term}

About one-third of utilities require residential customers to subscribe to green pricing programs for a minimum period of time, while $44 \%$ have an enrollment-term requirement for nonresidential customers (Table 21). One year is the most common minimum enrollment period, with requirements ranging from three months to five years for residential customers and three months to 10 years for nonresidential customers. In some cases, utilities require nonresidential customers to enroll for longer periods of time than residential customers. Among all respondents, 7\% require enrollment terms of more than one year for residential customers, while $12 \%$ require nonresidential enrollment beyond one year. Despite the existence of these contract requirements, some utilities have reported that they are not enforced.

Table 21: Enrollment Term by Customer Segment

\begin{tabular}{|l|c|c|}
\hline & Residential & Nonresidential \\
\hline Percent of utilities with a minimum enrollment term & $33 \%$ & $44 \%$ \\
\hline Most common enrollment term & 1 year & 1 year \\
\hline Range of contract terms & $\begin{array}{c}3 \text { months to } 5 \\
\text { years }\end{array}$ & $\begin{array}{c}3 \text { months to } 10 \\
\text { years }\end{array}$ \\
\hline
\end{tabular}

\section{Program Evaluations and Market Research}

Nearly two-thirds $(63 \%)$ of respondents reported that they had conducted customer research to aid the design of their green pricing program or to develop a marketing plan. Of the 34 programs that conducted customer research, about half did so in 2003 and nearly half did so in multiple years. In addition, $59 \%$ of utilities indicated that they had conducted a program evaluation. Of the 32 programs that conducted one or more program 
evaluations, 29 did so in 2003 and nearly one-third did so in multiple years. Statistics for the top performing programs are similar- $69 \%$ conducted customer research while $63 \%$ conducted program evaluations.

\section{Customer Value}

Response to utility green pricing programs can be influenced by additional values offered to customers. For example, customers may be more willing to participate in a program if their participation is recognized or rewarded, or if they receive other products and services, such as compact fluorescent light bulbs or store discounts. Wiser et al. (2004) found evidence that providing additional values increases green power purchase rates among nonresidential customers.

Table 22 indicates the number and percentage of utilities that provide additional benefits to customers, based on a list of options included in the 2002 and 2003 questionnaires. Of the 11 options listed, respondents indicated that their utilities offered an average of three additional benefits to their green pricing customers. The most common methods were 1) to inform customers about the status of the program through newsletters that provide periodic program updates, and 2) to provide decals that can be displayed in windows. Other types of customer recognition were also common. For example, in 2003, 51\% of utilities reported that they recognized business-customer participation in program advertisements or local media, while $49 \%$ reported that they provided customers with plaques or other items. Twenty-nine percent of utilities provided customers with tours of renewable energy projects. Twelve percent of utilities indicated that they provided customers with compact fluorescent light bulbs or other energy efficiency products.

Comparing the offerings between program years, it appears that more programs are offering recognition for businesses as well as recognition plaques in 2003. More programs may be choosing to offer this recognition in place of benefits such as tours, installations on schools, education programs, or efficiency products - the number of programs offering these incentives has declined.

The top performing programs were more likely to offer all of the benefits listed in Table 22 , with the exception of installations on schools or educational programs. For example, $87 \%$ of the top performers provided newsletters to participants with program updates and $73 \%$ provided plaques or recognition to participants, compared to $64 \%$ and $49 \%$ of all programs, respectively. The top performers were also more likely to protect customers from fuel cost increases, provide discounts or promotions at local businesses, and provide decals for display in store windows. The top performers reported providing an average of four of the benefits listed, compared to an average of three for all programs. 
Table 22: Methods of Providing Additional Program Benefits

\begin{tabular}{|c|c|c|c|c|c|}
\hline & $\begin{array}{c}2002 \\
\text { Positive } \\
\text { Responses }\end{array}$ & $2002 \%$ & $\begin{array}{c}2003 \\
\text { Positive } \\
\text { Responses }\end{array}$ & $2003 \%$ & $\begin{array}{c}\text { Top } \\
\text { Performers } \\
2003 \%^{*} \\
\end{array}$ \\
\hline Newsletters that provide program updates & 39 & $61.9 \%$ & 38 & $64.4 \%$ & $86.7 \%$ \\
\hline Decals for display in store windows & 37 & $58.7 \%$ & 33 & $55.9 \%$ & $66.7 \%$ \\
\hline $\begin{array}{l}\text { Recognition of business customers in } \\
\text { program ads or local media }\end{array}$ & 28 & $44.4 \%$ & 30 & $50.8 \%$ & $53.3 \%$ \\
\hline Plaques or other items for recognition & 25 & $39.7 \%$ & 29 & $49.2 \%$ & $73.3 \%$ \\
\hline Tours to renewable energy project sites & 22 & $34.9 \%$ & 17 & $28.8 \%$ & $33.3 \%$ \\
\hline $\begin{array}{l}\text { Installations on schools/renewable energy } \\
\text { education programs }\end{array}$ & 19 & $30.2 \%$ & 15 & $25.4 \%$ & $20.0 \%$ \\
\hline $\begin{array}{l}\text { Compact fluorescents or efficiency } \\
\text { products }\end{array}$ & 14 & $22.2 \%$ & 7 & $11.9 \%$ & $13.3 \%$ \\
\hline $\begin{array}{l}\text { Discounts or promotions at local } \\
\text { businesses }\end{array}$ & 5 & $7.9 \%$ & 7 & $11.9 \%$ & $26.7 \%$ \\
\hline Other & 3 & $4.8 \%$ & 7 & $11.9 \%$ & $26.7 \%$ \\
\hline Protection from fuel-cost increases & 7 & $11.1 \%$ & 6 & $10.2 \%$ & $33.3 \%$ \\
\hline Exemption from environmental fees & 1 & $1.6 \%$ & 1 & $1.7 \%$ & $6.7 \%$ \\
\hline
\end{tabular}

\section{Conclusions and Observations}

The availability of green pricing and consumer response to these programs continue to show steady growth, indicating that the market is receptive to the idea of consumerdriven investments in renewable energy capacity. In 2003, about 500 utilities (or $16 \%$ of all utilities nationally) offered green pricing programs to nearly 33 million customers in 34 states.

Both participant and sales numbers continued to grow in 2003, with sales increasing at a more rapid rate. The number of customers participating in utility green pricing programs increased by $16 \%$ to approximately 265,000 participants, while sales increased by $44 \%$ to approximately 1.3 billion kWh annually. The higher growth rate in sales can be attributed to the larger number of customers purchasing green power-particularly new nonresidential customers - as well as larger purchases by customers. However, green pricing sales represent a very small fraction of total utility sales, with an average considerably below $1 \%$ - although some utilities have achieved sales penetration rates of as much as $3 \%$. 
Although consumer response has grown steadily in recent years, a relatively small number of green pricing programs continue to dominate participation and sales figures. In fact, only 10 programs accounted for about three-quarters of customer participants and $85 \%$ of green energy sales in 2003 . And one program accounted for nearly one-fourth of all sales with a fixed-price product that protects participating customers from fuel-cost increases for up to 10 years. This strategy has proved to be very popular among nonresidential customers and, if replicated, could increase industry sales dramatically.

While participation rates in green pricing programs have remained relatively steady at about $1 \%$, programs that have existed for at least four years exhibit participation rates near $2 \%$. Therefore, persistence in marketing appears to play a role in garnering customers. ${ }^{10}$ The most successful programs have achieved participation rates of between $4 \%$ and $7 \%$, with one utility breaking the $10 \%$ threshold. This suggests that higher rates are possible with successful marketing and outreach campaigns, or perhaps in programs that offer superior value propositions. However, these rates are still well below the 50\% to $70 \%$ of customers who indicate they are willing to pay a premium for green power in market research surveys (Farhar, 1999).

Price premiums have continued to decline in recent years, a trend that could prove to be important for attracting more price-sensitive customers, such as businesses and other nonresidential customers. The average price premium for green power decreased at an average annual rate of nearly $10 \%$ since 2000 to $2.6 \phi / \mathrm{kWh}$ in 2003 , while the median premium declined to $2.0 \notin / \mathrm{kWh}$. Only a handful of programs offer lower premiums for large, nonresidential purchasers, which could become problematic for maintaining significant nonresidential sales as competition from lower-priced REC-based offerings increases.

At the end of 2003, about $520 \mathrm{MW}$ of new renewable energy capacity was serving customers participating in utility green pricing programs, with another $170 \mathrm{MW}$ planned. Thus, green pricing is proving to be a viable strategy for supporting the development of new renewable energy sources. Because the current success can be attributed to a relatively small number of programs, the challenge going forward is to translate the success of the top performing programs to the rest of the industry.

\footnotetext{
${ }^{10}$ This finding is also supported by a statistical analysis of program effectiveness conducted by Wiser et al. (2004).
} 


\section{References}

Bird, L. and B. Swezey, 2003. Green Power Marketing in the United States: A Status Report (Sixth Edition), NREL/TP-620-35119. Golden, CO: National Renewable Energy Laboratory, October. http://www.eere.energy.gov/greenpower/pdf/35119.pdf

Bird, L. and B. Swezey, 2004. Estimates of New Renewable Energy Capacity Serving U.S. Green Power Markets (2003). Golden, CO: National Renewable Energy Laboratory, May. http://www.eere.energy.gov/greenpower/resources/tables/new_gp_cap.shtml

Bird, L., B. Swezey, and J. Aabakken, 2004. Utility Green Pricing Programs: Design, Implementation, and Consumer Response. Report prepared by National Renewable Energy Laboratory, Golden Colorado, February. NREL/TP-620-35618. http://www.eere.energy.gov/greenpower/resources/pdfs/nrel 35618.pdf

Etra, D., 2003. Powerful Choices IV: A Survey of Retail Green Power Programs in the Pacific Northwest, Renewable Northwest Project, Portland, Oregon, August. http://www.rnp.org/News/pr PwrChcs4.html

Farhar, B., 1999. Willingness to Pay for Electricity from Renewable Resources: A Review of Utility Market Research, NREL/TP-550-26148. Golden, CO: National Renewable Energy Laboratory, July. http://www.eere.energy.gov/greenpower/farhar_26148.html

Harris, N., 2002. Powerful Choices III: A Survey of Retail Green Power Programs in the Pacific Northwest and Beyond. Portland, OR: Renewable Northwest Project, August. http://www.rnp.org/Resources/PC3Intro.html

Holt, E. and M. Holt, 2004. Green Pricing Resource Guide. Second Edition (Review Draft). Prepared for the American Wind Energy Association, Washington, D.C.

Lieberman, D., 2002. Green Pricing at Public Utilities: A How-To Guide Based on Lessons Learned to Date. San Francisco, CA: Center for Resource Solutions, October. http://www.resource-solutions.org/pdf/PRP.Green.Pricing.Report.10.29.02.pdf

Swezey, B. and L. Bird, 2001. Utility Green Pricing Programs: What Defines Success? NREL/TP-620-29831. Golden, CO: National Renewable Energy Laboratory, August. http://www.eere.energy.gov/greenpower/29831.pdf

Swezey, B. and L. Bird, 2000. Green Power Marketing in the United States: A Status Report (Fifth Edition), NREL/TP-620-28738. Golden, CO: National Renewable Energy Laboratory, August. http://www.eere.energy.gov/greenpower/pdf/28738.pdf

Swezey, B. and L. Bird, 1999. Information Brief on Green Power Marketing (Fourth Edition), NREL/TP-620-26901. Golden, CO: National Renewable Energy Laboratory, August. http://www.nrel.gov/analysis/emaa/brief_4.html 
Washington Department of Community, Trade and Economic Development (CTED) and Utilities Transportation Commission (UTC), 2002. Green Power Programs in

Washington: A Report to the Legislature. Olympia, WA, December.

http://www.cted.wa.gov/DesktopDefault.aspx?tabid=440

Washington Department of Community, Trade and Economic Development (CTED) and Utilities Transportation Commission (UTC), 2003. Green Power Programs in

Washington: A Report to the Legislature. Olympia, WA, December.

http://www.cted.wa.gov/uploads/Green\%20Power\%2011-24-03.doc

Wiser, R., S. Olson, L. Bird and B. Swezey, 2004. Utility Green Pricing Programs: A Statistical Analysis of Program Effectiveness, LBNL-54437. Berkeley, CA: Lawrence Berkeley National Laboratory, February.

http://www.eere.energy.gov/greenpower/resources/pdfs/lbnl 54437.pdf 


\section{Appendix A}

\section{Utility Green Pricing Program Questionnaire}

Confidentiality - Individual utility responses to this survey regarding customers, sales, and marketing information will be held confidential. Data are used to prepare NREL's list of top ten utility green pricing programs and to provide aggregate industry data to the U.S. DOE and the general public.

1. Utility name

2. Name of respondent (phone/email)

3. Name of green power program

(if you have multiple programs, please fill out a separate form for each program)

4. Year program was launched

5. In which states is the program offered?

\section{Participation}

6. In the table below, please provide participation data as of December 31, 2003. If data is provided for a different month (e.g., November) please specify

\begin{tabular}{|l|l|}
\hline Question & Response \\
\hline Total number of residential green power participants & \\
\hline Total number of non-residential green power participants & \\
\hline Number of new residential green power participants in 2003 & \\
\hline Number of new non-residential green power participants in 2003 & \\
\hline Number of residential customers (or members) eligible to participate & \\
\hline Number of non-residential customers (or members) eligible to participate & \\
\hline Is the program currently open to new customers? Yes/No & \\
\hline Number of customers on waiting list & \\
\hline Number of participants who have dropped out of the program this year & \\
\hline Minimum period of time residential customers must participate (e.g., 1 year) & \\
\hline Minimum period of time non-residential customers must participate (e.g., 2 years) & \\
\hline
\end{tabular}

7. For programs that are offered to multiple distribution cooperatives or municipal utilities, please list any individual utilities that have achieved participation rates of $3 \%$ or higher.

Sales for 2003

8. In the table below, please indicate the sales of green power to customers during the previous 12-months.

Please also indicate the top 3 non-residential purchasers and the amount purchased in 2003.

\begin{tabular}{|l|l|l|l|}
\hline Green power sales for most recent 12 months & $\begin{array}{l}\text { Number of } \\
\text { Blocks Sold }\end{array}$ & Block size & $\begin{array}{l}\text { KWh/year of green } \\
\text { power }\end{array}$ \\
\hline Green power sales to residential customers & & & \\
\hline Green power sales to non-residential customers & & & \\
\hline Top 3 non-residential purchasers: & & & \\
\hline 1. & & & \\
\hline 2. & & & \\
\hline 3. & & & \\
\hline
\end{tabular}


Renewable Energy Supplies

9. In the table below, please indicate the type and amount of renewable resources sold to participants in your green pricing program during 2003 and any new capacity planned for the future.

\begin{tabular}{|l|l|l|l|l|}
\hline & $\begin{array}{l}\text { Nameplate } \\
\text { Capacity } \\
\text { Installed }(\mathrm{kW})\end{array}$ & $\begin{array}{l}\text { Year } \\
\text { Installed }\end{array}$ & $\begin{array}{l}\text { Energy or REC } \\
\text { Purchases in 2003 } \\
(\mathrm{kWh} / \mathrm{yr})\end{array}$ & $\begin{array}{l}\text { Nameplate Capacity } \\
\text { Planned }(\mathrm{kW})\end{array}$ \\
\hline Wind & & & & \\
\hline PV & & & & \\
\hline Hydro & & & & \\
\hline Geothermal & & & & \\
\hline Landfill methane & & & & \\
\hline Other (please specify) & & & & \\
\hline
\end{tabular}

10 . Of the renewable energy used to supply your program in 2003, what percentage came from the following?

\begin{tabular}{|l|l|l|r|l|l|}
\hline $\begin{array}{l}\text { Renewable projects owned or } \\
\text { partially-owned by your utility }\end{array}$ & $\%$ & $\begin{array}{l}\text { Renewable energy } \\
\text { purchases from others }\end{array}$ & $\%$ & $\begin{array}{l}\text { Renewable } \\
\text { certificate purchases }\end{array}$ & $\%$ \\
\hline
\end{tabular}

\section{Premium}

11. Please indicate the price premium charged for this green power product (i.e., $\$ / \mathrm{kWh}$ block, $\phi / \mathrm{kWh}$, $\$ / \mathrm{kW}$, or minimum suggested contribution)

12. Please indicate the premium for nonresidential customers, if different.

13. Was there a change in the premium in 2003 ? Yes/No

If so, why?

14. What is the minimum purchase for residential participants (e.g. 2 blocks or $25 \%$ of usage)?

15. What is the nonresidential minimum purchase (e.g. 100 blocks or $10 \%$ of usage)?

16. Are green power customers protected, by virtue of their green power purchase, from increases in fuel costs (i.e., natural gas) or non-renewable energy fees (i.e., emissions control fees)? Yes/No If so, how?

\section{Green Power Program Design and Implementation}

17. Have you performed (in 2003 or earlier) market research to aid in the design of your green power product or development of your marketing plan? Yes/No If yes, in what year?

18. Have you performed an evaluation of the program (in 2003 or earlier)? Yes/No

If yes, in what year? W _ What aspect of the program was evaluated?

19. In which of the following ways can customers sign up for your program? (check all that apply)

\begin{tabular}{|l|l|l|l|}
\hline Utility Web site & & By returning a mail-in card & \\
\hline Checking a box on their electric bill & & By phone through the utility call center & \\
\hline Sign up at special events & & Other? & \\
\hline
\end{tabular}

20. What other value-added products or services do you provide to customers that enroll in your green power program? (check all that apply)

\begin{tabular}{|l|l|l|l|}
\hline Compact fluorescents or efficiency products & & Decals for display in store windows & \\
\hline $\begin{array}{l}\text { Recognition of business customers in program } \\
\text { ads or local media }\end{array}$ & & $\begin{array}{l}\text { Installations on schools/renewable energy } \\
\text { education programs }\end{array}$ & \\
\hline Discounts or promotions at local businesses & & Plaques or other items for recognition & \\
\hline Newsletters that provide program updates & & Protection from fuel cost increases & \\
\hline Tours to renewable energy project sites & & Exemption from environmental fees & \\
\hline
\end{tabular}

\section{Marketing and Administration}

21 . How much do you spend annually on marketing the program, excluding staff time?

22. How much do you spend annually on program administration, including staff time?

23. What percentage of your green power premium was attributable to marketing and administrative costs in 2003 ? 
24. Are all costs born by program participants? Yes/No If no, please explain

25. On average, how much do you spend to sign up each residential customer (\$/customer)?

26. In the table below, please indicate which marketing strategies you used to promote your green power program in 2003. (check all that apply)

\begin{tabular}{|l|l|l|l|l|l|}
\hline Bill inserts & Television & Telemarketing & \\
\hline Direct mail & Radio & & Billboards & \\
\hline Utility newsletter & Newspaper & & Publicity/feature stories (non-paid) & \\
\hline
\end{tabular}

Please email or fax this questionnaire by Friday, January 23 to: Lori Bird, lori bird@nrel.gov, Fax (303) 384-7411. If questions, please call Lori Bird at (303) 384-7412. 


\section{Appendix B}

Table B-1: Utilities Offering Green Pricing Programs in 2003

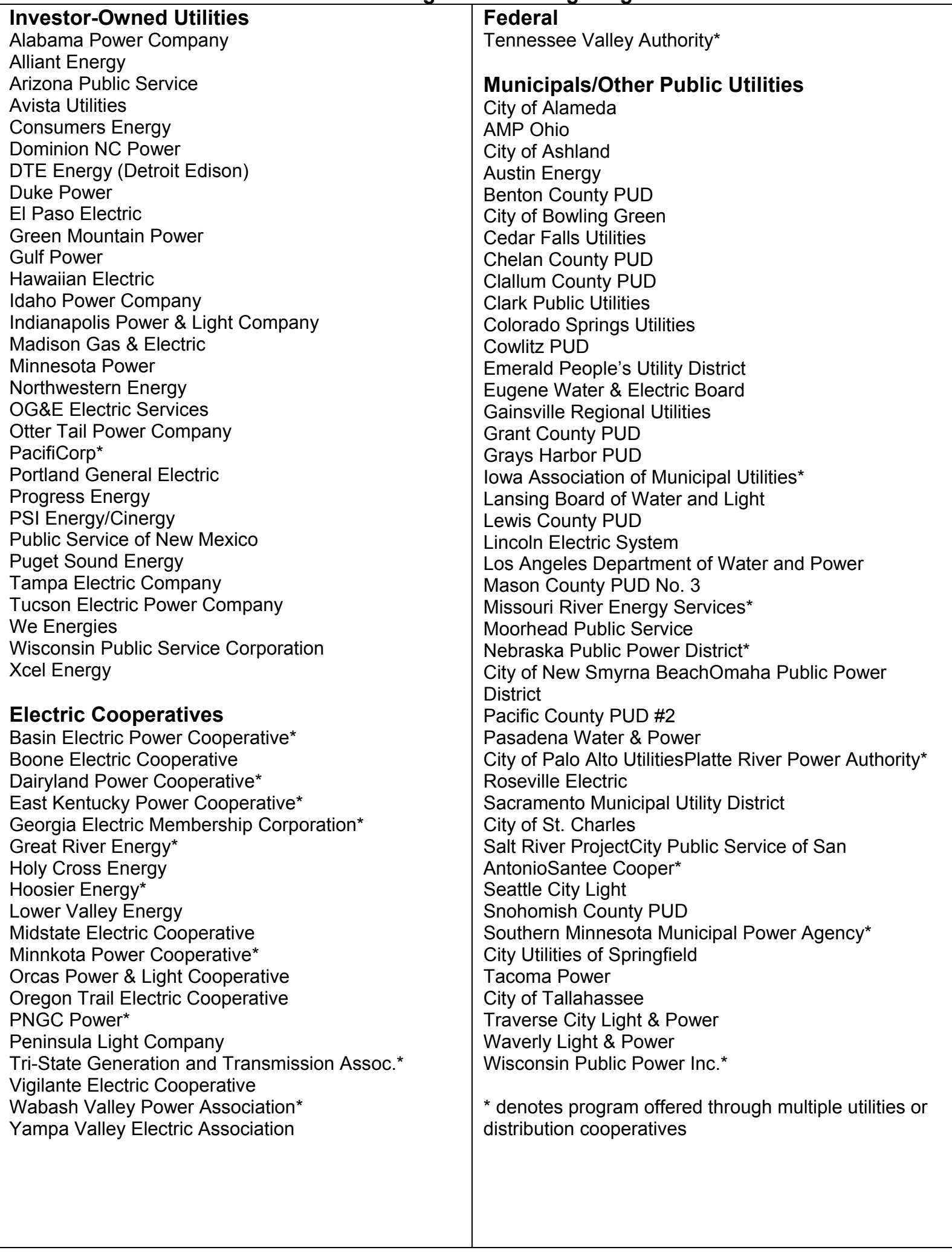




\section{Appendix C}

Table C-1: Green Pricing Program Renewable Energy Sales (as of December 2003)

\begin{tabular}{|c|c|c|c|c|}
\hline Rank & Utility & Resources Used & $\begin{array}{c}\text { Sales } \\
\text { (kWh/year) }\end{array}$ & $\begin{array}{l}\text { Sales } \\
(\text { aMW })^{a}\end{array}$ \\
\hline 1 & Austin Energy & Wind and landfill gas & $289,038,019$ & 33.0 \\
\hline 2 & Portland General Electric ${ }^{b}$ & Wind and geothermal & $188,646,290$ & 21.5 \\
\hline 3 & Sacramento Municipal Utility District ${ }^{d}$ & Landfill gas, wind, hydro & $143,160,698$ & 16.3 \\
\hline 4 & PacifiCorp ${ }^{b}$ & Wind and geothermal & $132,168,603$ & 15.1 \\
\hline 5 & Xcel Energy & Wind & $123,700,000$ & 14.1 \\
\hline 6 & $\begin{array}{l}\text { Los Angeles Department of Water \& } \\
\text { Power }\end{array}$ & $\begin{array}{c}\text { Small hydro, landfill gas, } \\
\text { solar }\end{array}$ & $87,845,342^{c}$ & 10.0 \\
\hline 7 & Tennessee Valley Authority $^{d}$ & Biogas, wind, solar & $40,491,000$ & 4.6 \\
\hline 8 & We Energies $^{d}$ & Landfill gas, wind, hydro & $34,648,566$ & 4.0 \\
\hline 9 & Alliant Energy ${ }^{d}$ & Wind and landfill gas & $27,958,473$ & 3.2 \\
\hline 10 & Puget Sound Energy & Wind and solar & $27,312,900$ & 3.1 \\
\hline
\end{tabular}

a An "average megawatt" (aMW) is a measure of capacity equivalent that assumes the capacity operates continuously.

${ }^{\mathrm{b}}$ Marketed in partnership with Green Mountain Energy Company.

${ }^{\mathrm{c}}$ Data is for 2002.

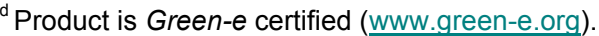


Table C-2: Total Number of Customer Participants (as of December 2003)

\begin{tabular}{|c|c|c|c|}
\hline Rank & Utility & Program Name(s) & Participants \\
\hline 1 & Xcel Energy & $\begin{array}{l}\text { Windsource } \\
\text { Renewable Energy Trust }\end{array}$ & 43,039 \\
\hline 2 & Los Angeles Department of Water \& Power & Green Power for a Green $L A$ & $37,386^{a}$ \\
\hline 3 & Portland General Electric ${ }^{b}$ & $\begin{array}{l}\text { Clean Wind } \\
\text { Renewable Usage } \\
\text { Healthy Habitat }\end{array}$ & 26,893 \\
\hline 4 & Sacramento Municipal Utility District & $\begin{array}{l}\text { Greenergy } \\
\text { PV Pioneers I }\end{array}$ & 24,542 \\
\hline 5 & PacifiCorp ${ }^{b}$ & $\begin{array}{l}\text { Blue Sky } \\
\text { Renewable Usage } \\
\text { Habitat Option }\end{array}$ & 23,351 \\
\hline 6 & We Energies & Energy for Tomorrow ${ }^{c}$ & 10,760 \\
\hline 7 & Alliant Energy & Second Nature ${ }^{c}$ & 9,519 \\
\hline 8 & Austin Energy & GreenChoice & 7,462 \\
\hline 9 & Tennessee Valley Authority & Green Power Switch ${ }^{\mathrm{C}}$ & 7,364 \\
\hline 10 & Wisconsin Public Service & $\begin{array}{l}\text { SolarWise for Schools } \\
\text { NatureWise }^{\mathrm{c}}\end{array}$ & 6,157 \\
\hline
\end{tabular}

a as of May 2003.

${ }^{\mathrm{b}}$ Marketed in partnership with Green Mountain Energy Company.

${ }^{c}$ Product is Green-e certified (www.green-e.org). 
Table C-3: Customer Participation Rate

(as of December 2003)

\begin{tabular}{|c|c|c|c|c|}
\hline Rank & Utility & $\begin{array}{c}\text { Customer } \\
\text { Participation } \\
\text { Rate } \\
\end{array}$ & Program(s) & $\begin{array}{c}\text { Program } \\
\text { Start } \\
\text { Year } \\
\end{array}$ \\
\hline 1 & Lenox Municipal Utilities $^{a}$ & $11.1 \%$ & Green City Energy & 2003 \\
\hline 2 & City of Palo Alto Utilities ${ }^{b}$ & $6.6 \%$ & Palo Alto Green ${ }^{\mathrm{d}}$ & 2003 \\
\hline 3 & Moorhead Public Service & $5.5 \%$ & Capture the Wind & 1998 \\
\hline 4 & Holy Cross Energy & $5.1 \%$ & $\begin{array}{l}\text { Wind Power Pioneer } \\
\text { Local Renewable Energy Pool }\end{array}$ & $\begin{array}{l}1998 \\
2002\end{array}$ \\
\hline 5 & $\begin{array}{l}\text { Montezuma Municipal Light and } \\
\text { Power }^{a}\end{array}$ & $4.9 \%$ & Green City Energy & 2003 \\
\hline 5 & Orcas Power \& Light & $4.9 \%$ & Go Green & 1999 \\
\hline 7 & City of Fairbank ${ }^{a}$ & $4.7 \%$ & Green City Energy & 2003 \\
\hline 8 & Sacramento Municipal Utility District & $4.6 \%$ & $\begin{array}{l}\text { Greenergy } \\
\text { PV Pioneers I }\end{array}$ & $\begin{array}{l}1997 \\
1993\end{array}$ \\
\hline 9 & Central Electric Cooperative $^{c}$ & $4.1 \%$ & Green Power & 1999 \\
\hline 10 & Madison Gas \& Electric & $3.9 \%$ & Wind Energy Program & 1999 \\
\hline
\end{tabular}

a Program offered in association with the lowa Association of Municipal Utilities.

${ }^{\mathrm{b}}$ Product marketed in partnership with 3 Phases Energy Services

${ }^{\mathrm{C}}$ Power supplied by PNGC Power.

${ }^{\mathrm{d}}$ Product is Green-e certified (www.green-e.org). 
Table C-4: Price Premium Charged for New, Customer-Driven Renewable Power ${ }^{a}$ (as of December 2003)

\begin{tabular}{|c|c|c|c|}
\hline Rank & Utility & Resources Used & $\begin{array}{c}\text { Premium } \\
\text { (ф/kWh) }\end{array}$ \\
\hline 1 & Austin Energy ${ }^{\mathrm{b}}$ & Wind and landfill gas & 0.59 \\
\hline 2 & OG\&E Electric Services ${ }^{b}$ & Wind & 0.63 \\
\hline 3 & Clallam County Public Utility District ${ }^{\mathrm{b}}$ & Landfill gas & 0.70 \\
\hline 4 & Wabash Valley Power Association $^{\mathrm{C}}$ & Landfill gas & 0.90 \\
\hline 5 & Roseville Electric & Geothermal and solar & 1.00 \\
\hline 5 & Sacramento Municipal Utility District ${ }^{d}$ & Landfill gas, wind, hydro & 1.00 \\
\hline 5 & Southern Minnesota Municipal Power Agency & Wind & 1.00 \\
\hline 8 & Emerald People's Utility District ${ }^{e}$ & Wind & 1.20 \\
\hline 9 & American Municipal Power $-\mathrm{Ohio}^{\mathrm{e}}$ & Hydro, wind & 1.30 \\
\hline 9 & Eugene Water and Electric Board ${ }^{\mathrm{b}}$ & Wind & 1.30 \\
\hline
\end{tabular}

${ }^{a}$ Includes only programs that have installed or announced firm plans to install or purchase power from $100 \%$ new renewable resources.

${ }^{\mathrm{b}}$ Premium is variable; customers in these programs are exempt or otherwise protected from changes in utility fuel charges.

${ }^{\mathrm{c}}$ The premium charged by participating member distribution utilities varies from $0.9 \phi / \mathrm{kWh}$ to $1.0 \phi / \mathrm{kWh}$.

${ }^{\mathrm{d}}$ Product is Green-e certified (www.green-e.org).

${ }^{\mathrm{e}}$ Product is marketed in partnership with Green Mountain Energy Company. 


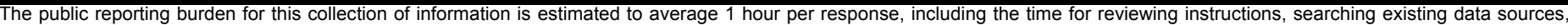

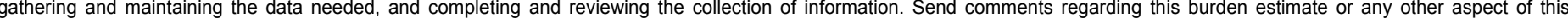

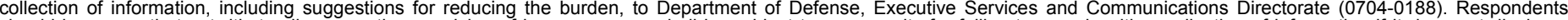

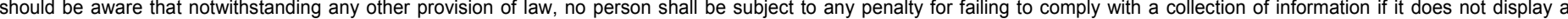
currently valid OMB control number.

PLEASE DO NOT RETURN YOUR FORM TO THE ABOVE ORGANIZATION.

\begin{tabular}{|c|c|}
\hline - REPORT DATE (DD-MM-YYYY) & 2. REPORT TYPE \\
\hline
\end{tabular}

4. TITLE AND SUBTITLE

Trends in Utility Green Pricing Programs (2003)

3. DATES COVERED (From - To)

5a. CONTRACT NUMBER

DE-AC36-99-G010337

5b. GRANT NUMBER

5c. PROGRAM ELEMENT NUMBER

6. AUTHOR(S)

Lori Bird and Karen Cardinal

5d. PROJECT NUMBER

NREL/TP-620-36833

5e. TASK NUMBER

ASG4.1003

5f. WORK UNIT NUMBER

7. PERFORMING ORGANIZATION NAME(S) AND ADDRESS(ES)

National Renewable Energy Laboratory

1617 Cole Blvd.

8. PERFORMING ORGANIZATION

REPORT NUMBER

Golden, CO 80401-3393

NREL/TP-620-36833

9. SPONSORING/MONITORING AGENCY NAME(S) AND ADDRESS(ES)

10. SPONSOR/MONITOR'S ACRONYM(S) NREL

11. SPONSORING/MONITORING AGENCY REPORT NUMBER

12. DISTRIBUTION AVAILABILITY STATEMENT

National Technical Information Service

U.S. Department of Commerce

5285 Port Royal Road

Springfield, VA 22161

\section{SUPPLEMENTARY NOTES}

14. ABSTRACT (Maximum 200 Words)

Utilities first began offering consumers a choice of purchasing electricity generated from renewable energy sources in the early 1990s. Since then, the number of U.S. utilities offering green pricing programs has steadily grown. Today, more than 500 utilities in regulated electricity markets-or about $16 \%$ of all utilities nationally-offer their customers green power options. Because some of these utilities offer programs in conjunction with cooperative associations or other public power entities, the number of distinct programs is slightly more than 100. Through these programs, more than 33 million customers spanning 34 states have the ability to purchase renewable energy to meet some portion or all of their electricity needs, or make contributions to support the development of renewable energy resources.

Typically, customers must pay a premium above standard electricity rates for this service. This report presents yearend 2003 data on utility green pricing programs, and examines trends in consumer response and program implementation over time. The data provided in this report can be used by utilities as benchmarks by which to gauge the success of their green power programs.

\section{SUBJECT TERMS}

Green power; green pricing; utilities; 2003; electricity customers; public power; renewable energy supplies; renewable energy certificates; green power products; customer-acquisition costs; marketing costs; investor-owned utilities; IOUs; RECs; Lori Bird; Karen Cardinal.

\begin{tabular}{|c|c|c|c|c|}
\hline 16. SECURIT & CLASSIFICATI & N OF: & 17. LIMITATION & 18. NUMBER \\
\hline $\begin{array}{l}\text { a. REPORT } \\
\text { Unclassified }\end{array}$ & $\begin{array}{l}\text { b. ABSTRACT } \\
\text { Unclassified }\end{array}$ & $\begin{array}{l}\text { c. THIS PAGE } \\
\text { Unclassified }\end{array}$ & $\begin{array}{l}\text { OF ABSTRACT } \\
\text { UL }\end{array}$ & \\
\hline
\end{tabular}

19a. NAME OF RESPONSIBLE PERSON

19b. TELEPONE NUMBER (Include area code) 